\title{
Flora do Ceará, Brasil: Polygalaceae
}

\author{
Flora of Ceará, Brazil: Polygalaceae
}

\author{
Igor Gonçalves Lima ${ }^{1}$, Alex Melo Lins Albuquerque ${ }^{1}$, Ana Cristina Andrade de Aguiar Dias ${ }^{2}$ \\ \& Maria Iracema Bezerra Loiola ${ }^{3,4}$
}

\begin{abstract}
Resumo
O objetivo deste trabalho foi realizar o levantamento florístico dos representantes de Polygalaceae, como parte do projeto Flora do Ceará. O estudo foi baseado na análise de caracteres morfológicos de espécimes obtidos em campo e em coleções dos herbários EAC, BHCB, HST, HVASF, RB e UFP. As excursões ao campo foram realizadas no período de setembro/2015 a março/2016. As identificações foram feitas com o auxílio de bibliografias especializadas, confirmadas pela análise de coleções-tipo. Para o estado do Ceará foram reconhecidas 20 espécies pertencentes a sete gêneros: Acanthocladus (1), Asemeia (3), Bredemeyera (2), Caamembeca (1), Moninna (1), Polygala (9) e Securidaca (3). As espécies foram registradas em diferentes tipos de vegetação, mas ocorrem preferencialmente na savana-estépica (caatinga) e savana (cerrado) e 13 espécies (62\%) em cinco Unidades de Conservação. Moninna insignis e Polygala celosioides constituem novos registros para o estado do Ceará.
\end{abstract}

Palavras-chaves: diversidade, Fabales, Neotrópicos, taxonomia.

\begin{abstract}
This study aimed carry out the floristic inventory of Polygalaceae species, as part of Flora of Ceará project. The study was based in the analysis of morphological characters of specimens obtained in field or in herborized collections from herbaria EAC, BHCB, HST, HVASF, RB and UFP. The field expeditions were realized between September/2015 and March/2016.. The identifications were based on specialized bibliography, confirmed by analysis of collections-types. In the Ceará State, 20 species and seven genera were registered: Acanthocladus (1) Asemeia (3), Bredemeyera (2), Caamembeca (1), Monnina (1), Polygala (9) and Securidaca (3). The species were registered in distincts vegetation types, but occurs, preferably, in stepic savannah (caatinga) and savannah (cerrado) and 13 (62\%) were recorded in five Conservations Units. Monnina insignis and Polygala celosioides are new records for Ceará state.
\end{abstract}

Key words: diversity, Fabales, Neotropics, taxonomy.

\section{Introdução}

Polygalaceae Hoffmanns. \& Link compreende 19 gêneros e aproximadamente 1.300 espécies com ampla distribuição no planeta, não ocorrendo apenas nos polos e na Nova Zelândia (Marques \& Peixoto 2007; Leite et al. 2015). Na flora brasileira a família está representada por onze gêneros e 199 espécies, das quais 123 são endêmicas (BFG 2015). Polygala L. é o gênero mais representativo, com aproximadamente 120 espécies distribuídas por todas as regiões do país (BFG 2015).
Economicamente, algumas espécies de Polygala têm importância medicinal pela presença de salicilato de metila no córtex da raiz, sendo este muito usado em medicamentos para o tratamento de contusões e dores musculares (Marques 1996). Polygala paniculata L. possui propriedades analgésicas, anti-edematogênicas e gastroprotetoras (Victório et al. 2011), sendo também usada como ornamental (Paiva 1988). Em algumas espécies de Polygalaceae foram detectados saponinas, xantonas, cumarinas, ácidos graxos,

\footnotetext{
${ }^{1}$ Universidade Federal do Ceará, Depto. Biologia, B1. 906, Campus do Pici, 60440-900, Fortaleza, CE, Brasil.

${ }^{2}$ Universidade Federal do Pará, Inst. Ciências Biológicas, Av. Perimetral 2501, Montese, 66077-530, Belém, PA, Brasil.

${ }^{3}$ Universidade Federal do Ceará, Depto. Biologia, Herbário EAC, Lab. Sistemática e Ecologia Vegetal, B1. 906, Campus do Pici, 60440-900, Fortaleza, CE, Brasil.

${ }^{4}$ Autor para correspondência: iloiola@ufc.br
} 
fenóis e alcaloides (Silveira et al. 1995; Oliveira et al. 2000; Pizzolatti et al. 2004).

No Brasil, o estudo mais detalhado sobre a família foi desenvolvido por Bennet (1874), que na Flora brasiliensis considerou oito gêneros e 137 espécies, das quais várias eram novas para a Ciência. Mais recentemente, os representantes de Polygalaceae foram estudados em diferentes regiões e citados em floras regionais e locais.

No nordeste brasileiro foram realizados o levantamento dos representantes de Polygala ocorrentes na Paraíba (Coelho et al. 2008) e de Polygalaceae em Alagoas (Lemos et al. 2010) e Sergipe (Ferreira \& Alves 2015). Especificamente para o estado do Ceará, nenhum estudo recente foi desenvolvido com as espécies desta família e seus representantes raramente são citados nos levantamentos florísticos, sendo o número de espécies listadas muito reduzido (Araújo et al. 2011; Loiola et al. 2015). Merece destacar que os números indicados para a flora do Ceará estão desatualizados e estudos vinculados ao "Projeto Flora do Ceará: conhecer para conservar" têm mostrado o quanto a diversidade florística do estado está subestimada, com ocorrência de novos registros (Capistrano \& Loiola 2015; Tabosa et al. 2016) ou descrição de novas espécies (Loiola 2013; Sampaio et al. 2016; Souza et al. 2016; Ribeiro \& Loiola 2017).

Esse trabalho objetivou, portanto, realizar o levantamento florístico das espécies de Polygalaceae no Ceará, visando contribuir para um melhor conhecimento da diversidade desse grupo e entendimento da distribuição das espécies que compõem a flora desse estado.

\section{Material e Métodos}

Caracterização da área de estudo: $\mathrm{O}$ estado do Ceará localiza-se na região Nordeste do Brasil e possui uma área de $148.886,3 \mathrm{~km}^{2}$, ocupando $1,75 \%$ da área do país (IPECE 2013). É composto por 184 municípios, dos quais $93 \%$ inseremse no semiárido nordestino, caracterizado pela irregularidade pluviométrica, tendo em média 3-4 meses de chuva por ano (IPECE 2013). No estado, o regime climático predominante é o Tropical Quente Semiárido com variação da temperatura média anual entre 24 e $26^{\circ} \mathrm{C}$ e precipitação média anual que não ultrapassa $1.000 \mathrm{~mm}$ (Nimer 1972; Lima et al. 2000).

Identificação, descrição e distribuição geográfica das espécies: A identificação das espécies se baseou na análise comparativa de estruturas morfológicas vegetativas e reprodutivas de espécimes coletados em campo e depositados nos herbários BHCB, EAC, HST, HVASF, RB e UFP, cujas siglas estão de acordo com Thiers (continously update), além de tipos e fotografias de tipos disponíveis nos sítios dos Herbários F, K, Lista da Flora do Brasil e SpeciesLink. As excursões para a obtenção das amostras foram realizadas no período de setembro/2015 a março/2016 em diferentes municípios cearenses.

As identificações foram feitas com base em descrições originais e bibliografias especializadas e para a confirmação dos nomes dos táxons foi consultado o sítio IPNI (2017). As descrições das espécies foram baseadas principalmente em amostras coletadas no Ceará e feitas com o auxílio de microscópio estereoscópico e paquímetro, utilizando-se a terminologia proposta por Radford et al. (1974) e Stearn (1992). Em alguns casos, dado ao considerável número de espécimes analisadas, optamos por citar apenas algumas coleções como material selecionado. Por não haver material florido na amostra de Acanthocladus dichromus (Steud.) J.F.B.Pastore (= Acanthocladus albicans A.W.Benn.) coletado no Ceará, a descrição floral foi realizada a partir da análise do material adicional oriundo do estado de Pernambuco (M.S. Sobrinho 307 UFP).

Os dados fitogeográficos, forma de crescimento (hábito), fenologia e nome popular foram obtidos através dos dados das etiquetas das exsicatas. A distribuição das espécies em território brasileiro foi baseada em BFG (2015).

Para a vegetação, foi adotada a classificação do Manual Técnico da Vegetação Brasileira (IBGE 2012): savana (Cerrado), savana estépica (Caatinga/Carrasco), floresta estacional decidual (mata seca), floresta ombrófila densa (mata úmida), floresta estacional sempre verde (mata úmida), floresta estacional semidecidual das terras baixas (mata de tabuleiro) e vegetação com influência marinha (restinga). Já a distribuição geográfica das espécies no Ceará foi indicada através do sistema de quadrículas georreferenciadas (Fig. 1) proposto por Menezes et al. (2013).

\section{Resultados e Discussão}

Polygalaceae Hoffmanns. \& Link, Fl. Portug. 1: 62. 1809. (nom. cons.).

Ervas, subarbustos, arbustos eretos a escandentes ou árvores. Folhas simples, alternas, opostas ou verticiladas, inteiras, glabras ou pilosas. Inflorescências em racemos, panículas ou fascículos 


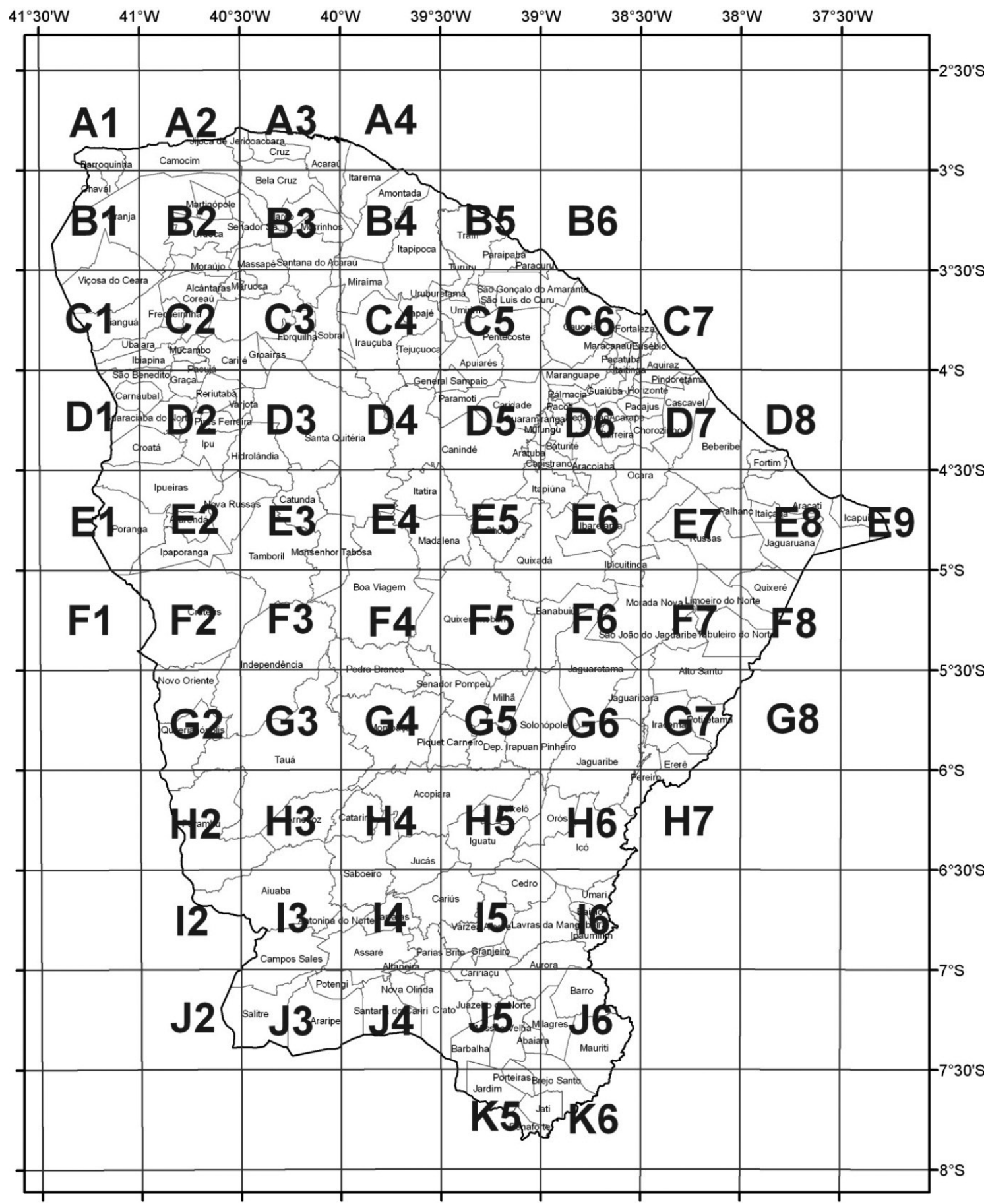

Figura 1 - Divisão política do estado do Ceará com grade de coordenadas de meio grau (A1-K6) (Menezes et al. 2013). Figure 1 - Political division of the state of Ceará with a half degree grid (A1-K6) (Menezes et al. 2013). 
umbeliformes, terminais, axilares ou opositifolios. Bractéolas caducas ou não. Flores actinomorfas ou zigomorfas, dióicas; cálice 4-5, geralmente com três sépalas externas e duas internas, petaloides; pétalas 3-5, geralmente duas laterais, rudimentares ou desenvolvidas e uma carena central cuculada ou ainda ausentes; estames 8 , epipétalos ou com filetes unidos basalmente formando uma bainha aberta, frequentemente adnata em seu dorso às pétalas; anteras basifixas, com rimas oblíquas que se convergem para o ápice; ovário súpero, 1,2,5locular, 1 óvulo por lóculo, anátropo, epítropo ou pêndulo. Fruto baga, cápsula loculicida, núcula ou sâmara; sementes 1-5, pilosas ou glabras, com ou sem arilo, com ou sem endosperma.

Para o estado do Ceará foram registradas 20 espécies de Polygalaceae, pertencentes a sete gêneros: Acanthocladus Klotzsch ex Hassk. (1), Asemeia Raf. emend. Small. (3), Bredemeyera Willd. (2), Caamembeca J.F.B. Pastore (1), Monnina Ruiz \& Pav. (1), Polygala L. (9) e Securidaca L. (3). O gênero Monnina, representado por $M$. insignis Willd. e Polygala celosioides Mart. ex A.W. Benn. constituem novos registros para o estado.

Polygalaceae está bem representada no estado do Ceará, onde foram registrados 63,33\% dos gêneros citados para o Brasil. No território cearense foi encontrada a maior diversidade de gêneros e espécies em relação aos demais estados da região Nordeste, uma vez que foram registrados três gêneros e 11 espécies para Alagoas (Lemos et al. 2010) e seis gêneros e 20 espécies para Sergipe (Ferreira \& Alves 2015).
Os representantes de Polygalaceae ocorrem em todo o território cearense e a maioria das espécies se desenvolve na savana (cerrado) e savana-estépica (caatinga). Asemeia violacea (Aubl.) J.F.B. Pastore e Polygala boliviensis A.W.Benn. são as espécies com mais ampla distribuição no estado; já Acanthocladus dichromus, Caamembeca spectabilis (DC.), Polyagala appendiculata Vell. e P. celosioides Mart. ex A.W.Benn. têm distribuição restrita no território cearense e foram registradas em apenas um ou dois municípios.

Um total de 13 espécies (aproximadamente $62 \%$ ) foram registradas em cinco Unidades de Conservação do Ceará: Floresta Nacional do Araripe (Asemeia violacea, Bredemeyera brevifolia, Caamembeca spectabilis, Polygala gracilis, Securidaca diversifolia, S. lanceolata), Parque Nacional de Ubajara (Asemeia martiana) Estação Ecológica de Aiuaba (Asemeia violacea, Polygala boliviensis), RPPN Serra das Almas (Asemeia martiana, Asemeia ovata, Bredemeyera floribunda, Polygala glochidata, P. longicaulis), Parque Botânico do Ceará (Asemeia ovata, Polygala glochidata). Esses dados indicam que um número considerável de representantes de Polygalaceae estão se desenvolvendo em áreas consideradas protegidas. No entanto, evidencia-se a necessidade de intensificar os estudos sobre as espécies de Polygalaceae no território cearense, visando a obtenção de maiores informações sobre o status de conservação de todos os representantes dessa família no referido estado.

\section{Chave de identificação das espécies de Polygalaceae ocorrentes no Ceará}

1. Ramos terminais com espinhos; inflorescência em fascículos umbeliformes

1'. Ramos sem espinhos; inflorescência em racemos ou panículas.

2. Erva, subarbusto, arbusto ou árvore; carena sem crista.

3. Erva; fruto nucóide, 2-alado 5.1. Monnina insignis

3'. Subarbusto, arbusto ou árvore; fruto cápsula ou sâmara 1-alada.

4. Nectários extraflorais cilíndricos, 0,7-1,4 mm compr.

4'. Nectários extraflorais circulares, 0,1-0,2 mm compr. ou ausentes.

5. Cápsula espatulada, indeiscente.

6. Folhas com ápice emarginado e face adaxial velutina; estilete pubérulo na base 3.1. Bredemeyera brevifolia

6'. Folhas com ápice agudo e face adaxial glabra ou glabrescente; estilete glabro 3.2. Bredemeyera floribunda

5'. Cápsula oblonga, deiscente.

7. Ervas a subarbustos com ramos eretos ou decumbentes. 
8. Folhas lineares ou estreito a largo-lanceoladas; pedicelo pubérulo ... 2.3. Asemeia violacea

8'. Folhas elípticas, obovadas ou oblanceoladas; pedicelo glabro.

9. Ramos eretos; folhas elípticas

2.1. Asemeia martiana

9'. Ramos decumbentes; folhas obovadas ou oblanceoladas 2.2. Asemeia ovata

7'. Arbustos com ramos eretos ou escandentes.

10. Folhas com tricomas patentes na face abaxial

7.1. Securidaca coriacea

10'. Folhas com tricomas adpressos na face abaxial.

11. Folhas ovadas com base arredondada; pétalas laterais externas 1,8-2,4 mm larg., obovadas a subobovadas com ápice arredondado 7.2. Securidaca diversifolia

11'. Folhas lanceoladas a elípticas com base aguda; pétalas laterais externas 4,1-5 mm larg., subespatuladas com ápice ligeiramente flabelado 7.3. Securidaca lanceolata

2'. Erva; carena com ápice cristado.

12. Ramos com tricomas falciformes

6.2. Polygala boliviensis

12'. Ramos glabros ou com tricomas eretos, lepidotos ou glandulares, nunca falciformes.

13. Sementes recobertas por tricomas uncinados

6.4. Polygala glochidata

13'. Sementes glabras, glabrescentes ou recobertas por tricomas eretos.

14. Folhas alterno-espiraladas; sementes glabras ou glabrescentes

6.3. Polygala celosioides

14'. Folhas alternas ou verticiladas; sementes recobertas por tricomas eretos, formando ou não uma coroa de tricomas na base.

15. Racemos cônicos

6.8. Polygala sedoides

15'. Racemos espiciformes ou subcapitados.

16. Sementes sem apêndices.

17. Racemos subcapitados; sementes triangulares, com coroa de tricomas na base 6.6. Polygala longicaulis

17'. Racemos espiciformes; sementes obovadas, sem coroa de tricomas na base 6.1. Polygala appendiculata

16'. Sementes com apêndices.

18. Racemos subcapitados; sementes triangulares, com coroa de tricomas na base 6.9. Polygala trichosperma

18'. Racemos espiciformes; sementes obovadas, sem coroa de tricomas na base.

19. Folhas lanceoladas; bractéola persistente no fruto; apêndices menor que a metade do comprimento da semente ... 6.5. Polygala gracilis

19'. Folhas lineares; bractéolas caducas; apêndices do mesmo tamanho ou maior que a metade do comprimento da semente 6.7. Polygala paniculata

1.1. Acanthocladus dichromus (Steud.) J.F.B.Pastore, Phytotaxa 286(1): 54-56. 2016.

Figs. 1; 2a

= Acanthocladus albicans A.W.Benn., Fl. bras. 13(3): 46. 1874.

Arbusto até $3 \mathrm{~m}$ alt., muito ramificado; ramos eretos, com espinhos de $8-10 \mathrm{~mm}$ compr. na porção terminal; ramos jovens recobertos por tricomas curtíssimos, ligeiramente falcados. Folhas alternas; lâmina 28-48 × 13-22 mm, ovada a elíptica, ápice agudo, base obtusa a arredondada, raríssimo aguda, face adaxial glabra ou com tricomas curtos na nervura principal, face adaxial glabra a glabrescente; pecíolo 2-4 mm compr., pubescente; nectários extraflorais ausentes. Fascículos umbeliformes 3-8 flores, subsésseis, axilares ou supra-axilares, raque glabra. Flores amarelo-claro; pedicelo 12-17 mm compr., glabro; 2 sépalas externas $2-4 \times 2-1,5 \mathrm{~mm}$, ovadas, oblatas ou suborbiculares, ápice ligeiramente obtuso, pilosas internamente, ciliadas; sépalas internas não observadas; 2 pétalas 5,5-6,2 × 1,8-2 $\mathrm{mm}$, oblanceoladas, ápice arredondado, pilosas internamente, ciliadas; 2 pétalas rudimentares, ca. $1,2 \times 0,5 \mathrm{~mm}$, lanceoladas, ápice arredondado, glabras; carena 4-5 × 6,4-8 mm, navicular, 

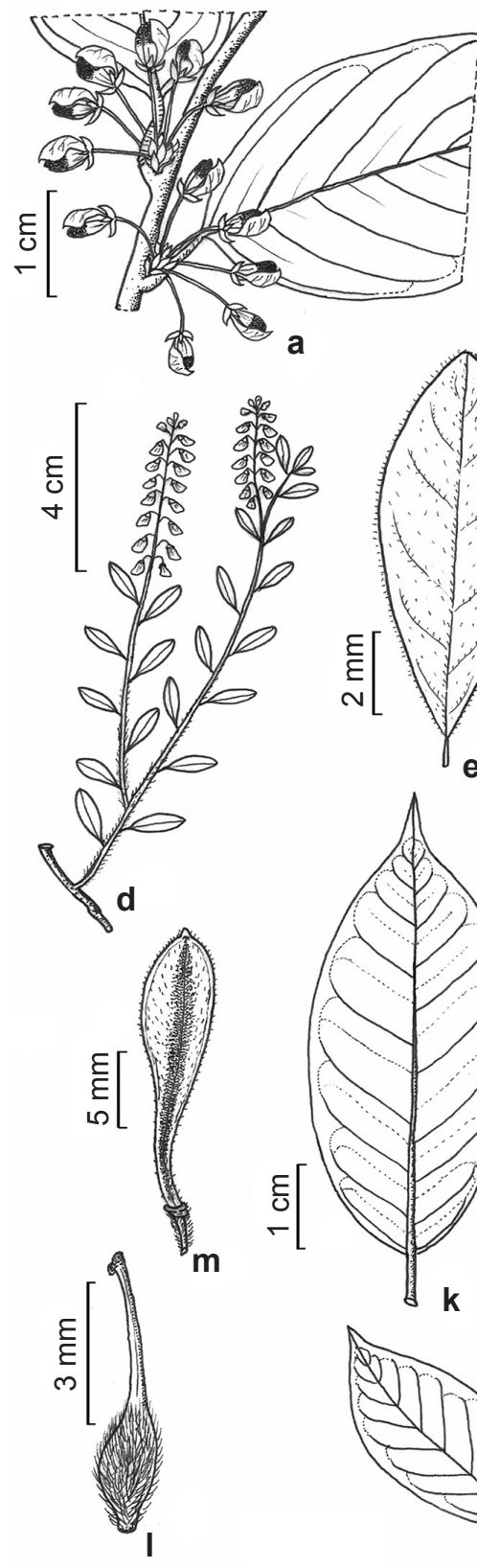
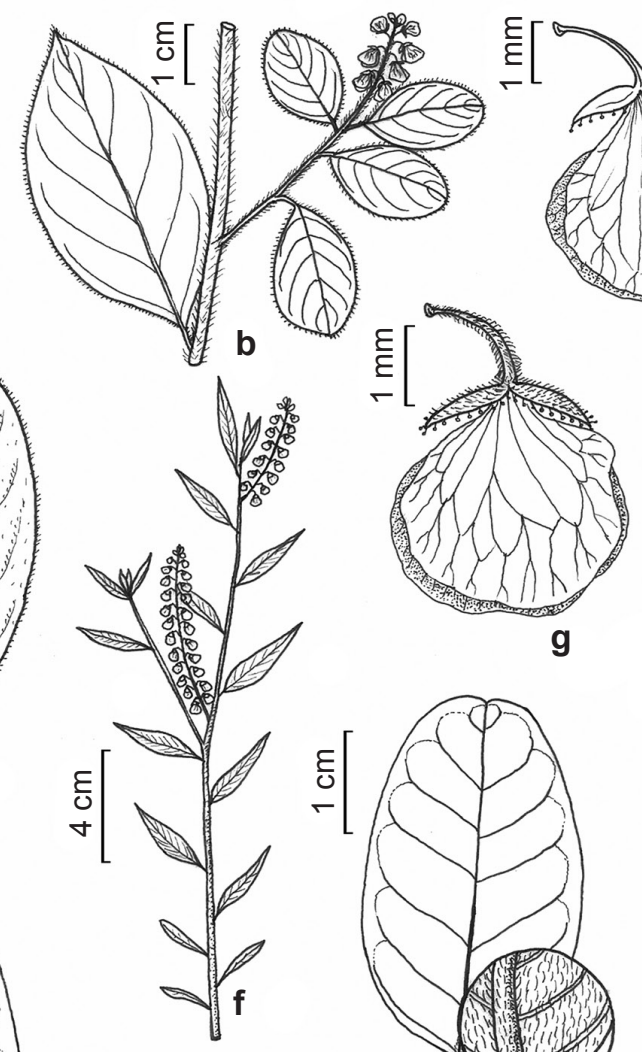

g
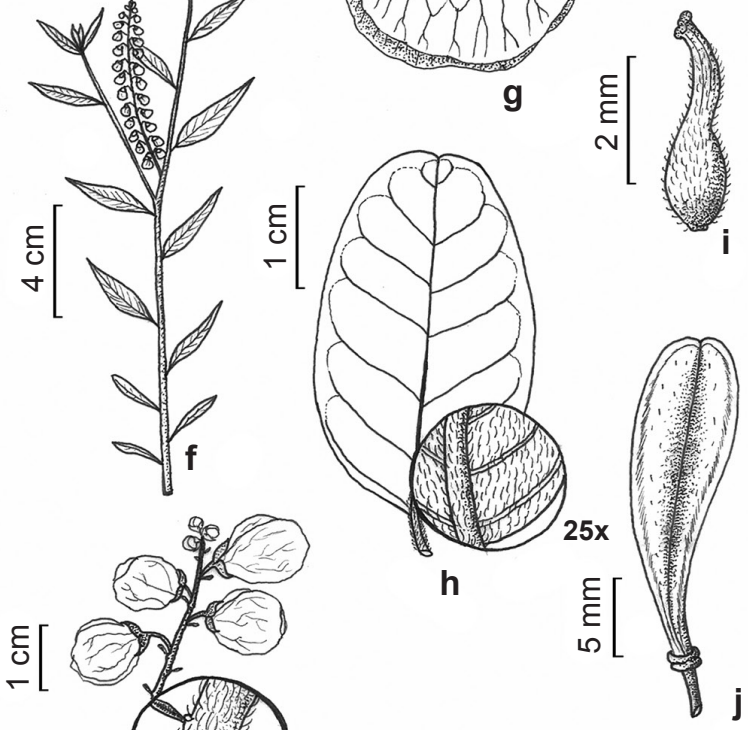

$\stackrel{\varepsilon}{\leftarrow}[$
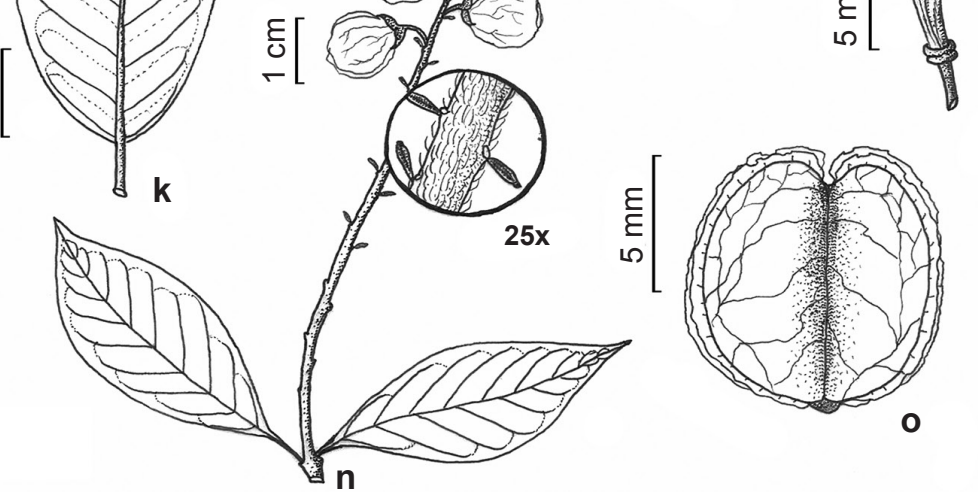

$\frac{\sqrt{2}}{\frac{2}{2}}$

Figura 2 - a. Acanthocladus albicans - a. inflorescência. b-c. Asemeia martiana - b. ramo com folha e inflorescência; c. flor. d-e. Asemeia ovata - d. ramo com folhas e inflorescência; e. face adaxial da folha. f-g. Asemeia violacea - f. ramo com folhas e inflorescência; g. flor. h-j. Bredemeyera brevifolia - h. face adaxial da folha; i. gineceu; j. fruto. k-m. B. floribunda - k. face adaxial da folha; 1 . gineceu; m. fruto. n-o. Caamembeca spectabilis - n. inflorescência; o. fruto. (a. M.S. Sobrinho 307; b-c. M.F. Moro 603; d-e. A. Fernandes - EAC 10435; f-g. A. Fernandes-EAC 13173; h-j. A. Fernandes e Matos - EAC 21464; k-m. E.M. Miranda et al. 92; n. E.B. Souza et al. 491; o. J.R. Maciel et al. 1053) Figure 2 - a. Acanthocladus albicans - a. inflorescence. b-c. Asemeia martiana - b. branch with leaf and inflorescence; c. flower. d-e. Asemeia ovata - d. branch with leaves and inflorescence; e. adaxial side of leaf. f-g. Asemeia violacea - f. branch with leaves and inflorescence; g. flower. h-j. Bredemeyera brevifolia - h. adaxial side of leaf; i. gynoecium; j. fruit. k-m. B. floribunda - k. adaxial side of leaf; 1. gynoecium; m. fruit. n-o. Caamembeca spectabilis - n. inflorescence; o. fruit. (a. M.S. Sobrinho 307; b-c. M.F. Moro 603; d-e. A. Fernandes - EAC 10435; f-g. A. Fernandes - EAC 13173; h-j. A. Fernandes e Matos - EAC 21464; k-m. E.M. Miranda et al. 92; n. E.B. Souza et al. 491; o. J.R. Maciel et al. 1053) 
cuculada, sem crista, pilosa internamente; bainha estaminal densamente ciliada nas laterais; estames 8, homodínamos, filetes 2-3 mm compr.; ovário ca. $2 \times 1,5 \mathrm{~mm}$, oval, glabro; estilete ca. $5 \mathrm{~mm}$ compr., glabro. Cápsula ca. $8 \mathrm{~mm}$ diâm., orbicular a suborbicular, lenhosa, glabra, com restos de sépalas. Sementes ca. $4 \mathrm{~mm}$ diâm., esféricas, glabras.

Material examinado: Mulungu, Sítio Jardim, 10.IX.2003, fr., V. Gomes et al. 793 (EAC).

Material adicional: MINAS GERAIS: Caratinga, Mata do Jaó, 7.X.2002, fl. e fr., J.V. Gomes (BHCB 75327). PERNAMBUCO: Exú, Fazenda Mata Fresca, 16.VII.1994, fl., S.F. Pinto 235 (EAC). São Lourenço da Mata, Estação Ecológica de Tapacurá, 21.VIII.2003, fl. e fr., M.S. Sobrinho 307 (UFP).

Acanthocladus dichromus é uma espécie bem definida e facilmente reconhecida por seus ramos terminais com espinhos, inflorescências em fascículos umbeliformes e cápsulas lenhosas. É nativa no Brasil, com distribuição nas regiões Nordeste, Sudeste e Centro-Oeste. No Ceará é uma espécie rara com registro apenas no município de Mulungu na serra de Baturité em floresta estacional decidual (Fig. 1; D5 e D6). Ressalta-se que tentamos recoletar esta espécie, mas devido à ausência das coordenadas geográficas na etiqueta da única amostra disponível, a mesma não foi encontrada. Coletada com frutos em setembro. Conhecida popularmente como "veludo".

2.1. Asemeia martiana (A.W. Benn.) J.F.B.Pastore \& J.R.Abbott, Kew Bull. 67(4): 808. 2012.

Figs. 1; 2b,c

Erva a subarbusto $18-40 \mathrm{~cm}$ alt., pouco ou muito ramificado; ramos eretos, sem espinhos; ramos e pecíolos pubérulos. Folhas alternas; lâmina 28-50 × 10-28 mm, elíptica, ápice frequentemente agudo e apiculado, raro obtuso ou arredondado, base aguda, ciliada, face adaxial glabra a glabrescente, face abaxial pubérula; pecíolo 3-5 mm compr.; nectários extraflorais ausentes. Racemos 2-4,4 cm compr., axilares ou supra-axilares, raque pilosa; bractéola central 0,8-1,5 mm compr., lanceolada, ciliada. Flores róseo-arroxeadas; pedicelo $1-1,8$ mm compr., glabro; 1 sépala externa maior 1,2-2 $\times$ 0,5-1 mm, ovada, côncava, ápice agudo, com tricomas glandulares capitados nas margens; 2 sépalas externas menores $1-1,7 \times 0,5-0,8 \mathrm{~mm}$, conatas, ovadas a lanceoladas, ápice agudo, com tricomas glandulares capitados nas margens; 2 sépalas internas, 4,1-5 × 3,5-4 mm, petaloides, subespatuladas, suborbiculares ou obovadas, ápice truncado a arredondado, emarginado ou não, glabras; 2 pétalas desenvolvidas 2,5-5 × 1,5-2,5 $\mathrm{mm}$, oblongas, ápice agudo, pubérula; carena 3-5,4 × 2-3,5 mm, navicular, cuculada, ápice emarginado, sem crista, levemente pubérula ou glabra externamente; estames 8, homodínamos, filetes ca. $1 \mathrm{~mm}$ compr.; ovário ca. $0,5 \mathrm{~mm}$ diâm., glabro; estilete 2,5-3 mm compr., glabro. Cápsula 3,5-4 × $2 \mathrm{~mm}$, oblonga, deiscente, glabra. Sementes 2,8-3,5 × 0,6-1,2 mm, cilíndricas, densamente revestidas por tricomas curtos adpressos, alvohialinos a acastanhados; carúncula com dois apêndices laterais e um dorsal, esparsamente pubérula.

Material selecionado: Crateús, RPPN Serra das Almas, 8.IV.2014, fl. e fr., D. Teixeira 45 (EAC). Fortaleza, Cambeba, 17.XII.2008, fl. e fr., M.F. Moro 603 (EAC). General Sampaio, Fazenda Natália, 29.IV.2007, fl. e fr., M.I.F. Moro et al. 82 (EAC). Icapuí, Ponta Grossa, 29.IV.2000, fl. e fr., Montenegro et al. 20 (EAC). São Gonçalo do Amarante, Dunas do Pecém, 13.VI.2004, fl. e fr., A.V. Vieira et al. (EAC 34231). Ubajara, Parque Nacional de Ubajara, 5.V.1979, fl. e fr., A.J. Castro et al. (EAC 6148).

Material adicional: RIO GRANDE DO NORTE: São Miguel do Gostoso, Novo Horizonte, 5¹6'57'S, 3544'28'W, 16.VII.2007, fl. e fr., M.I.B. Loiola et al. 1193 (EAC).

Asemeia martiana assemelha-se morfologicamente a $A$. violacea por serem ervas a subarbustos eretos e possuírem flores róseoarroxeadas e sementes cilíndricas, no entanto, podem ser facilmente distintas por $A$. martiana ter folhas elípticas ( $v s$. folhas lineares ou estrito a largo lanceoladas) e pedicelos glabros (vs. pubérulos). É endêmica do Brasil, com ocorrência confirmada apenas nas regiões Norte e Nordeste. Registrada no Ceará em vegetação de savana, savana-estépica, floresta estacional decidual sempre verde e floresta estacional semidecidual das terras baixas (Fig.1; C1, C2, C5, C6, C7, D4, D5, E2, E8, E9, F2, F3). Coletada com flores e frutos em abril, maio, junho e dezembro.

2.2. Asemeia ovata (Poir.) J.F.B.Pastore \& J.R.Abbott, Kew Bull. 67(4): 809. 2012.

Figs. 1; 2d,e

Erva a subarbusto $25-60 \mathrm{~cm}$ alt., pouco ou muito ramificado; ramos decumbentes, sem espinhos; ramos e pecíolos pubérulos. Folhas alternas; lâmina 18-46 × 5-30 mm, obovada ou oblanceolada, ápice frequentemente obtuso ou arredondado, raro agudo ou apiculado, base aguda a obtusa, margem ciliada, face adaxial 
recoberta por indumento regular por toda a lâmina ou adjacente às nervuras, face abaxial pubérula; pecíolo 1-3,8 mm compr.; nectários extraflorais ausentes. Racemos 2,8-5,4 cm compr., axilares ou supra-axilares, raque pilosa; bractéola central 0,9-1,2 mm compr., lanceolada, ciliada. Flores róseo-arroxeadas a esbranquiçadas; pedicelo 1,6-2 mm compr., glabro; 1 sépala externa maior 1,7-2 $\times$ 0,6-0,9 mm, ovada, côncava, ápice agudo, com tricomas glandulares capitados nas margens; 2 sépalas externas menores 1,5-1,8 × 0,5-0,7 mm, conatas, ovadas a lanceoladas, ápice agudo, com tricomas glandulares capitados nas margens; 2 sépalas internas, 4-5 × 3-3,5 mm, petaloides, subespatuladas a obovado-truncadas, ápice truncado, emarginado ou não, glabras; 2 pétalas desenvolvidas 3-4,4 × 0,8-2,5 mm, oblongas, ápice agudo ou arredondado, internamente pubérula; carena 3,5-5 × 2,2-4 $\mathrm{mm}$, navicular, cuculada, ápice emarginado, sem crista, levemente pubérula ou glabra externamente; estames 8 , homodínamos, filetes 1-1,5 mm compr.; ovário ca. 0,5-1 mm diâm., glabro; estilete 3-4,6 mm compr., glabro. Cápsula 3,5-5 × 2-3,2 mm, oblonga, deiscente, glabra. Sementes 3-3,5 × 0,8-1 mm, cilíndricas, densamente revestidas por tricomas curtos adpressos, alvo-hialinos a acastanhados; carúncula com dois apêndices laterais e um dorsal, esparsamente pubérula.

Material selecionado: Aquiraz, CEAC, 349'59"S, $38^{\circ} 25^{\prime} 17^{\prime \prime}$ 'W, 13.V.2016, fl. e fr., M.I.B. Loiola 2618 (EAC). Caucaia, Parque Botânico do Ceará, 27.V.1998, fl. e fr., E.B. Souza 251 (EAC). Crateús, RPPN Serra das Almas, 22.II.2000, fl. e fr., L.W. Lima-Verde 1152 (EAC). Fortaleza, São Gerardo, Campo da E.A.C., 8.VI.1956, fr., A. Fernandes (EAC 1606). Guaraciaba do Norte, Planalto da Ibiapaba. 21.III.1980, fl. e fr., A. Fernandes et al. (EAC 8244). Jati, estrada para São José do Belo Monte (PB), 38 58'34,5'S, 743'21,7'W, 18.II.2009, fl. e fr., J.G. Carvalho-Sobrinho et al. 1961 (EAC). São Benedito, Faveira, 7.VI.1981, fr., A. Fernandes et al. (EAC 10454). Tianguá, Serra da Ibiapaba, 8.III.1981, fl. e fr., A. Fernandes et al. (EAC 9907). Ubajara, Pavonia, 28.VI.1981, fl. e fr., A. Fernandes et al. (EAC 10435).

Material adicional: PERNAMBUCO: Buíque, 18.VI.1994, fl. e fr., A.M. Miranda et al. 1740 (EAC, HST).

Asemeia ovata diferencia-se das demais espécies do gênero registradas para o estado do Ceará por apresentar ramos decumbentes e folhas obovadas ou oblanceoladas, com face adaxial pubérula. Tem distribuição nas regiões Nordeste, Centro-Oeste e Sudeste. No Ceará foi registrada em floresta estacional decidual sempre verde e floresta estacional semidecidual das terras baixas, savana e áreas com interferência antrópica (Fig. 1; C1, C2, C6, C7, D1, D2, D7, E2, F2, F3). Encontrada com flores em fevereiro, março e maio e frutos em fevereiro, março, maio e junho.

2.3. Asemeia violacea (Aubl.) J.F.B.Pastore \& J.R.Abbott, Kew Bull. 67(4): 811. 2012.

Figs. 1; 2f,g

Erva a subarbusto $17-45 \mathrm{~cm}$ alt., pouco ou muito ramificado; ramos eretos, sem espinhos; ramos e pecíolos pubérulos. Folhas alternas; lâmina 23-50 × 3-25 mm, linear ou estreito a largolanceolada, ápice agudo, base aguda, ciliada, face adaxial glabra a glabrescente, face abaxial pubérula; pecíolo 1,5-3 mm compr.; nectários extraflorais ausentes. Racemos 3,2-7 cm compr., axilares ou supra-axilares, raque pubérulo; bractéola central 1-1,8 mm compr., lanceolada, ciliada. Flores róseo-arroxeadas; pedicelo 2-2,6 $\mathrm{mm}$ compr., pubérulo; 1 sépala externa maior 1,6-2 × 0,8-1 $\mathrm{mm}$, ovada, ápice agudo, côncava, com tricomas glandulares capitados nas margens; 2 sépalas externas menores $1-1,5 \times 0,3-0,6 \mathrm{~mm}$, conatas até a metade, ovadas a lanceoladas, ápice agudo, com tricomas glandulares capitados nas margens; 2 sépalas internas 2-4 × 2-3,6 mm, petaloides, subespatuladas, suborbiculares ou obovadas, ápice arredondado a truncado, emarginado ou não, glabras; 2 pétalas desenvolvidas 3-3,9 $\times$ 0,8-1,5 mm, ligeiramente espatuladas, ápice obtuso, internamente pubérula; carena 3-3,4 $\times$ 2-3 mm, navicular, cuculada, ápice emarginado, sem crista, externamente glabra; estames 8, homodínamos, filetes ca. $1 \mathrm{~mm}$ compr.; ovário ca. 0,5 mm diâm., glabro; estilete 2,3-3 mm compr., glabro. Cápsula 3,2-5 × 1,8-2,1 mm, oblonga, deiscente, glabra. Sementes 2,8-3,1 ×0,4-1,2 mm, cilíndricas, densamente revestidas por tricomas curtos adpressos, alvo-hialinos a acastanhados; carúncula com dois apêndices laterais e um dorsal, esparsamente pubérula.

Material selecionado: Aiuaba, Letreiro, 11.IV.1991, fl., M.A. Figueiredo 155 (EAC). Aquiraz, CEAC, 3049'59'S, 38²5'17'W, 13.V.2016, fl. e fr., M.I.B. Loiola 2621 (EAC). Canindé, Iguaçú, 26.VI.2008, fl. e fr., M.F. Moro et al. 495 (EAC). Coreaú, Ubauna, 28.III.1994, fl. e fr., M.A. Figueiredo et al. (EAC 21370). Crateús, Grajaú, 28.IV.2007, fl. e fr., L.P.A. Neto 88 (EAC). Crato, Floresta Nacional do Araripe, 22.V.1999, fl. e fr., A.M. Miranda et al. 3323 (HST). Fortaleza, Cidade dos Funcionários, 3.IV.1993, fl., I.M.B. Sá 06 (EAC). Irauçuba, 1.III.2007, fl. e fr., C.D.S. Pessoa 70 (EAC). Itapipoca, 25.IV.2011, fl. e fr., A.A. Lima et al. 2 (EAC). Jaguaribe, Maciço do Pereiro, 
12.IV.2011, fl. e fr., A.M. Miranda et al. 6335 (EAC). Jati, riacho Jardim, 0741'37,40”S, 03859'28,50"W, 10.IV.2013, fl. e fr., D.G. Oliveira et al. 994 (HVASF). Lavras da Mangabeira e Várzea Alegre, 17.V.1985, fl. e fr., A. Fernandes et al. (EAC 13173). Massapê, Fazenda Experimental UEVA, 8.VII.2013, fl. e fr., E.B. Souza et al. 2846 (EAC). Morada Nova, Fazenda Serraria, 25.IV.1997, fl. e fr., E.O. Barros 168 (EAC). Pedra Branca, BR 020, 27.IV.1981, fl. e fr., P. Martins (EAC 10142). Quixadá, Fazenda Olho D'água, 14.VI.1993, fl. e fr., Ivanilza (EAC 21816). Santa Quitéria, Fazenda Itataia, 27.IV.1984, fl. e fr., A. Fernandes (EAC 12521). Sobral, Fazenda UVA, 8.III.2005, fl. e fr., J.E. Alves et al. 21 (EAC). Tauá, Fazenda Boa Vista, 28.IV.1981, fl. e fr., E. Nunes et al. (EAC 10103).

Como já citado anteriormente, Asemeia violacea assemelha-se morfologicamente a $A$. martiana, diferenciando-se desta, principalmente pelas folhas lineares ou estreito a largo-lanceoladas e flores com pedicelo pubérulo. É nativa do Brasil e tem ampla distribuição no território brasileiro, estando presente em todas as regiões do país. É uma das espécies mais amplamente distribuída no Ceará, com registro em vegetação de savana, savana-estépica e áreas com interferência antrópica (Fig. 1; B2, B3, C2, C3, C4, C6, C7, D3, D4, D5, D7, E3, E4, E5, E7, F2, F3, F5, F6, F7, G2, G3, G4, G6, H2, H3, H6, K5, K6). Floresce e frutifica em janeiro, março, abril, maio, junho e julho.

3.1. Bredemeyera brevifolia (Benth.) Klotzsch ex A.W.Benn., Fl. bras. 13(3): 49. 1874.

Figs. $1 ; 2 \mathrm{~h}-\mathrm{j}$

Arbusto a árvore até $10 \mathrm{~m}$ alt., muito ramificados; ramos eretos ou às vezes escandentes, sem espinhos; indumento velutino alvo-amarelado nos ramos, face adaxial das folhas e pecíolos. Folhas alternas; lâmina 24-60×17-32 mm, oval a elíptica, ápice obtuso, frequentemente emarginado, base aguda a obtusa; pecíolo 3-5 mm compr.; nectários extraflorais $0,1-0,2 \mathrm{~mm}$, circulares. Panículas 3-10,5 cm compr., nas porções terminais dos ramos, recobertas por indumento tomentoso. Flores alvo-amareladas; pedicelo 2-4 mm compr., tomentoso; 1 sépala externa maior ca. $2 \times 2$ $\mathrm{mm}$, ovada, côncava, ápice agudo, ciliada; 2 sépalas externas menores 1-1,5 x $1 \mathrm{~mm}$, ovadas, ápice obtuso, base internamente pilosa, dorso tomentoso; 2 sépalas internas 3-4 × 2-3 mm, petaloides, laterais, suborbiculares a ovadas, ápice ligeiramente emarginado, margem ciliada; 2 pétalas laterais externas 2,4-3,3 × $2 \mathrm{~mm}$, obovadas a espatuladas, ápice obtuso, base internamente pilosa; 2 pétalas laterais internas rudimentares,
0,8-1 × 0,5 mm, elípticas, ápice agudo; carena 3-4 $\times$ 4-5 mm, navicular, cuculada, ápice ligeiramente emarginado, conata basalmente à bainha estaminal, sem crista; bainha estaminal côncava, densamente vilosa nas margens; estames 8 homodínamos, filetes 1-1,3 mm compr.; ovário ca. $1 \mathrm{~mm}$ diâm., ovoide, velutino; estilete ca. $3 \mathrm{~mm}$ compr., falcado, pubérulo na base. Cápsula 14-20 × 4-5 mm, espatulada, indeiscente, levemente velutina, ápice emarginado a mucronado. Sementes 6-10 $\times 2 \mathrm{~mm}$, oblongas, ápice levemente umbonado, ligeiramente sulcadas longitudinalmente, seríceas.

Material selecionado: Crato, Floresta Nacional do Araripe, 21.VII.2001, fr., I.R. Costa 329 (EAC). Guaraciaba do Norte, margem da rodovia para São Benedito, 3.I.1998, fl., A.S.F. Castro (EAC 25032). Novo Oriente, Baixa Fria, 28.III.1990, fr., F.S. Araújo 32 (EAC). São Benedito, Chapada da Ibiapaba, 29.XI.1990, fl., A. Fernandes et al. (EAC 16886). Tianguá, Chapada da Ibiapaba, 19.XI.1994, fl., A. Fernandes e Matos (EAC 21464). Ubajara, Ibiapaba, Jaburuna/Sul, 27.I.96, fl., F.S. Araújo 1161 (EAC).

Bredemeyera brevifolia se diferencia de $B$. floribunda por apresentar folhas ovais a elípticas com ápice emarginado ( $v s$. folhas elípticas com ápice frequentemente agudo a atenuado, raro emarginado), estilete pubérulo na base ( $v s$. estilete glabro) e sementes ligeiramente sulcadas longitudinalmente ( $v s$. sementes sem sulcos longitudinais). É uma espécie endêmica do Brasil com distribuição nas regiões Centro-Oeste, Sudeste e Nordeste. No Ceará foi registrada (Fig. 1; C1, C2, D1, D2, G2, J4, J5) em áreas de savana e savana-estépica. Coletada com flores de agosto a março e frutos de dezembro a agosto. Conhecida popularmente como "baquipari" ou "paquari".

3.2. Bredemeyera floribunda Willd., Ges. Naturf. Freunde Berlin Neue Schriften. 3: 412. 1801.

Figs. 1; 2k-m

Subarbusto a arbusto 2-3 m alt., muito ramificado; ramos escandentes, sem espinhos; indumento velutino nos ramos, face adaxial da folha e pecíolos. Folhas alternas; lâmina 55-112 $\times$ 24-45 mm, elíptica, ápice frequentemente agudo a atenuado, raro emarginado, base atenuada; pecíolo 5,7-9 mm compr.; nectários extraflorais $0,1-0,2$ mm, circulares. Panículas 15,5-20,1 cm compr., nas porções terminais dos ramos, com ou sem indumento tomentoso. Flores alvas a amareladas; pedicelo 1,7-2,3 mm compr., tomentoso; 1 sépala externa maior ca. $2 \times 3 \mathrm{~mm}$, ovada, ciliada; 2 sépalas externas menores ca. $2 \times 2 \mathrm{~mm}$, ovadas, internamente velutinas; 2 sépalas internas 3-4 
$\times 3 \mathrm{~mm}$, petalóides, laterais, ovadas a elípticas, internamente velutinas; 2 pétalas laterais externas $4,8-5,2 \times 2,8-3 \mathrm{~mm}$, subespatuladas, internamente velutinas; carena ca. $6 \times 4 \mathrm{~mm}$, navicular, cuculada, conata basalmente à bainha estaminal; bainha estaminal côncava, densamente vilosa nas margens; estames 8 homodínamos, filetes $1-1,2 \mathrm{~mm}$ compr.; ovário ca. $1 \mathrm{~mm}$ diâm., ovoide, viloso; estilete 3,4-4 mm compr., falcado, glabro. Cápsula 15-19 $\times$ 3-4 mm, espatulada, levemente velutina, verde quando imatura, ápice emarginado a mucronado. Sementes 9-12 × 1,2-1,4 mm, oblongas, ápice levemente umbonado, sem sulcos longitudinais, seríceas.

Material examinado: Arajara, 23.V.1996, fl., M.A.P. Silva (EAC 24096). Bom Jesus, Serra da Ibiapaba, 8.IX.2001, fr., A.S.F. Castro 1043 (EAC). Camocim, Boqueirão do Xavier, 8.IX.2005, A.S.F. Castro 1613 (EAC). Crateús, RPPN Serra das Almas, 25.V.2005, fl., F.S. Araújo et al. 1584 (EAC). Crato, Macaíbas, 27.VII.2001, fr., E. Silveira (EAC 30844). Guaraciaba do Norte, Planalto da Ibiapaba, 30.IV.2010, fr., E.M. Miranda et al. 92 (EAC). Jardim, 11.VI.1996, fl., M.A.P. Silva 106 (EAC 24109). Meruoca, Serra da Meruoca, 29.XI.2000, fl., $A$. Fernandes (EAC 30284). Milagres, Planalto da Ibiapaba, 10.III.1991, fl., F.S. Araújo 340 (EAC). Várzea Alegre, Naraniú, 18.V.1985, fl., A. Fernandes et al. (EAC 13198). Viçosa do Ceará, Sítio Bananeira, 28.XI.2002, fr., Abreu Matos et al. (EAC 32241).

Bredemeyera floribunda caracteriza-se por ser um subarbusto ou arbusto com folhas elípticas de ápice agudo a atenuado e estilete glabro. Assemelha-se morfologicamente a $B$. brevifolia e as características que as distinguem foram apresentadas nos comentários do último táxon. Ocorrem em todas as regiões do território brasileiro. No Ceará, se estabelece em áreas de savana, savanaestépica, floresta estacional decidual sempre verde e floresta estacional semidecidual das terras baixas (Fig. 1; A2, B1, C1, C2, C3, C6, D1, D2, F2, J4, J5, J6, K5, I5). Coletada com flores nos meses de abril, maio, junho, julho, agosto, setembro e novembro, e com frutos entre os meses de junho a novembro. Conhecida popularmente como "baquipari".

\subsection{Caamembeca spectabilis (DC. ) J.F.B.Pastore,} Kew Bull. 67(3): 439. $2012 . \quad$ Figs. 1; 2n,o

Subarbusto a arbusto até $1 \mathrm{~m}$ alt., pouco ou muito ramificado; ramos eretos, sem espinhos; ramos e pecíolos densamente pubérulos. Folhas alternas; lâmina 4-10 × 1,4-3,4 cm, elíptica, oblonga ou oblanceolada, ciliada, ápice atenuado a acuminado, base aguda, faces adaxial e abaxial pubérulas; pecíolo $3-5 \mathrm{~mm}$ compr.; nectários extraflorais $0,7-1,4 \mathrm{~mm}$ compr., cilíndricos, nos pecíolos e raque da inflorescência. Racemos 3,5-7,2 cm compr., na porção terminal dos ramos; 1 bractéola central 1,4-3 × $1 \mathrm{~mm}$, lanceolada, pubescente; 2 bractéolas laterais, 0,8-1,2 $\mathrm{mm}$ compr., ovadas a lanceoladas, pubescente. Flores alvo-amareladas a lilases; pedicelo $4,8-6 \mathrm{~mm}$ compr., pubérulo; 1 sépala externa maior $4,1-5$ $\times$ 5-6,1 mm, largo-ovada, ciliada, pubescente no dorso; 2 sépalas externas menores $2,1-3 \times 2,5-3$ $\mathrm{mm}$, suborbiculares, ciliadas, pubescentes no dorso; 2 sépalas internas 14-21 × 9-14 mm, petaloides, suborbiculares a largo-ovadas, ápice arredondado a obtuso, levemente ciliadas, dorso e ventre glabros; 2 pétalas desenvolvidas $21-24,5 \times 2,1-2,8$ $\mathrm{mm}$, linear, ápice arredondado a ligeiramente emarginado, glabra; 2 pétalas rudimentares, ca. $1,5 \times 0,8$, ligeiramente espatuladas a obovadas, ápice emarginado, conatas basalmente à carena; carena 18-23 mm compr., cuculada, sem crista, externamente glabra, levemente pubérula na face interna; bainha estaminal ca. $15 \mathrm{~mm}$ compr., glabra; estames 8 , homodínamos, filetes ca. 2 mm compr.; ovário 3-4 × 1,5-1,8 mm, oblongo a obovado, glabro; estilete 16-18 mm compr., glabro. Cápsula 1-1,2 $\times 0,8 \mathrm{~mm}$, oblonga, ligeiramente alada, glabra. Sementes 5-6 × 1,9-2,4 mm, bojudas a subtriangulares, densamente revestidas por tricomas curtos amarelo-hialinos; carúncula esparsamente pubérula, com um apêndice dorsal 4,2-5 mm compr., esparsamente pubérulo.

Material examinado: Barbalha, Sítio Santa Rita, 30.III.2000, fl., E.B. Souza et al. 491 (EAC); Cruzeiro, Chapada do Araripe, 39²0'51'"S, 7²2'58,8'W, 28.IV.2009, fr., J.R. Maciel et al. 1053 (HVASF). Crato, Flona do Araripe, 29.II.2000, fl., L.W. Lima-Verde 1950 (EAC).

Caamembeca spectabilis tem como características marcantes os ramos e pecíolos densamente pubérulos e os nectários extraflorais cilíndricos, com 0,7-1,4 mm compr. dispersos na raque e base dos pecíolos. É uma espécie nativa do Brasil com distribuição nas regiões Norte, em toda a região Nordeste e Sudeste. No Ceará, a espécie tem sua distribuição limitada ao extremo sul do estado, desenvolvendo-se preferencialmente em áreas úmidas como floresta estacional sempre verde, ocorrendo também em áreas de savana e savana-estépica (Fig.1; J4, J5). Coletada com flores em fevereiro e março e frutos em outubro.

5.1. Monnina insignis A.W.Benn., Fl. bras. 13(3): 56.1874.

Figs. 1; 3a,b

Erva $12-36 \mathrm{~cm}$ alt., pouco a muito ramificada; ramos eretos, sem espinhos; ramos e pecíolos 


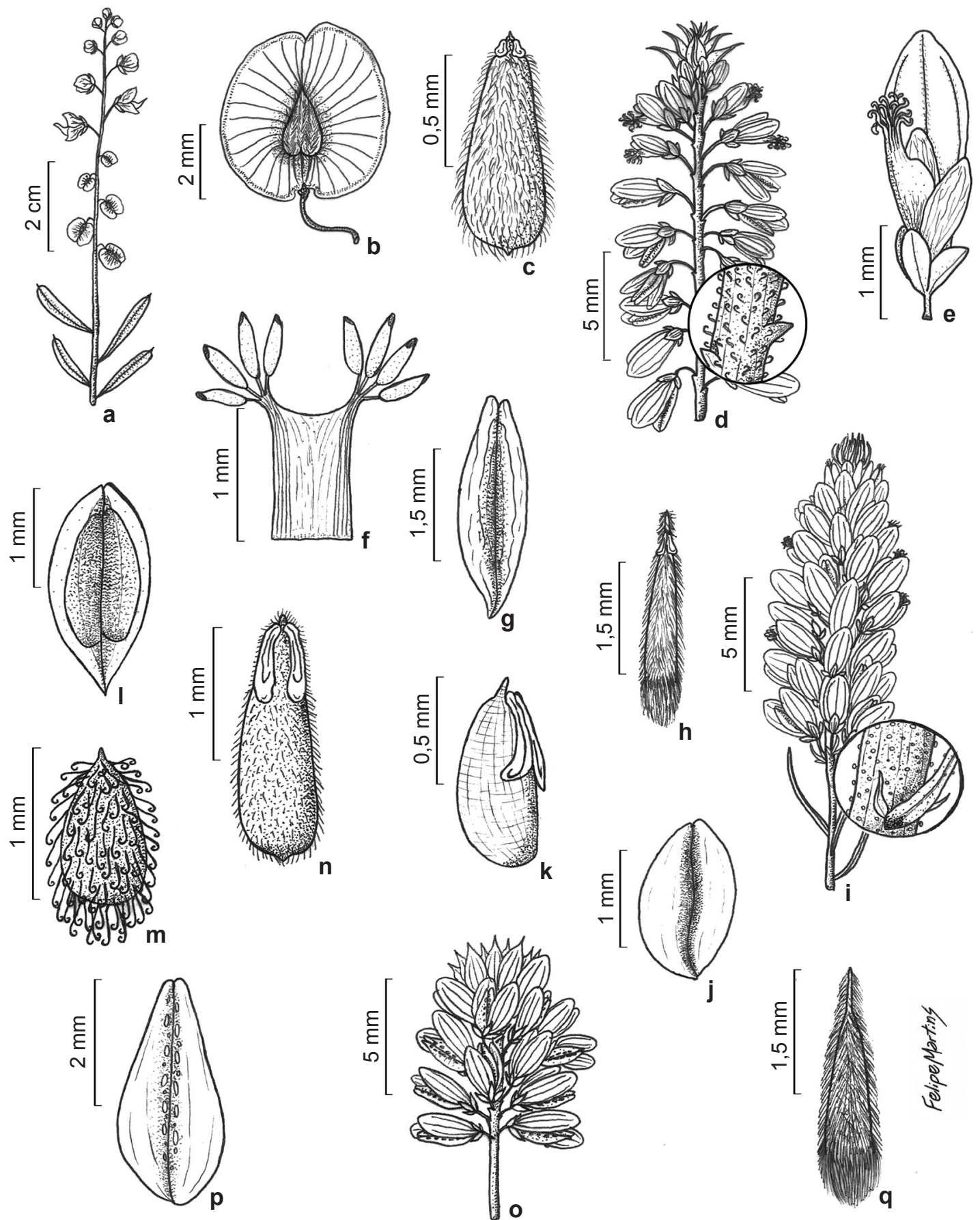

Figura 3 - a-b. Monnina insignis - a. ramo com inflorescência; b. fruto. c. Polygala appendiculata - c. semente. d-h. P. boliviensis - d. inflorescência; e. flor; f. bainha estaminal; g. fruto; h. semente. i-k. P. celosioides - i. inflorescência; j. fruto; k. semente. 1-m. P. glochidiata -1. fruto; m. semente. n. P. gracilis - n. semente. o-q. P. longicaulis - o. inflorescência; p. fruto; q. semente. (a-b. A.S.F. Castro 2743; c. D.J.L. Sousa 60; d-h. P. Martins - EAC 10248; i-k. A. Fernandes - EAC 3458; 1-m. F.S. Araújo 1495; n. L.W. Lima-Verde 2057; o-q. F.S. Araújo et al. 1385)

Figure 3 - a-b. Monnina insignis - a. branch with inflorescence; b. fruit. c. Polygala appendiculata - c. seed. d-h. P. boliviensis - d. inflorescence; e. flower; f. staminal sheath; g. fruit; h. seed. i-k. P. celosioides - i. inflorescence; j. fruit; k. seed. 1-m. P. glochidiata-1. fruit; m. seed. n. P. gracilis - n. seed. o-q. P. longicaulis - o. inflorescence; p. fruit; q. seed. (a-b. A.S.F. Castro 2743; c. D.J.L. Sousa 60; d-h. P. Martins - EAC 10248; i-k. A. Fernandes - EAC 3458; 1-m. F.S. Araújo 1495; n. L.W. Lima-Verde 2057; o-q. F.S. Araújo et al. 1385) 
recobertos por tricomas curtos e falciformes. Folhas alternas; lâmina 14-33 × 3-10 mm, elíptica a obovada, ápice frequentemente emarginado, às vezes apiculado, base aguda, face adaxial glabra a glabrescente, face abaxial pubescente; pecíolo 1-2,5 mm compr.; nectários extraflorais ausentes. Racemos 6,5-13 cm compr., nas porções axiais dos ramos. Flores amarelo-arroxeadas, bractéola central 1,6-2 mm compr., linear, caduca; pedicelo 1,2-2,7 mm compr.; 1 sépala externa maior $1,5-2,1 \times 0,8$ $\mathrm{mm}$, ovada, côncava, dorso pubérulo; 2 sépalas externas menores ca. $2 \times 1,2 \mathrm{~mm}$, elípticas, ápice arredondado, ciliadas; 2 sépalas internas 4-4,8 $\times$ 3,2-4 mm, petalóides, obovadas a suborbiculares, ápice arredondado, pubescentes; 2 pétalas laterais externas 2,1-2,5 × 0,8-1,1 mm, suboblongas, ápice obtuso, velutinas na base, conatas ao dorso da bainha estaminal; carena 6-6,8 × 4,5-5 mm, navicular, cuculada, trilobada, sem crista, velutina nos lobos laterais; bainha estaminal 2-2,5 compr., diadelfa, côncava, glabra no dorso; estames 8 , em duas séries de 4, homodínamos, filetes ausentes; ovário ca. 1 mm diâm., suborbicular, levemente viloso; estilete 6,5-8 mm compr., falcado, glabro. Fruto nucóide 68-80 × 65-75 mm, 2-alado, alas glabras, núcleo seminífero ca. $3 \times 2 \mathrm{~mm}$, hirsuto, bisseminado. Sementes ca. 1,5 $\times 0,8 \mathrm{~mm}$, ovoides, glabras. Material selecionado: Farias Brito, BR-230, 7.VI.1985, fl. e fr., A. Fernandes et al. (EAC 13253). Iguatu, rodovia entre Iguatu e Várzea Alegre, 29.III.19985, fl., $A$. Fernandes \& Matos (EAC 13074). Jaguaribe, estrada para Feiticeiro, 11.VII.2013, fl. e fr., A.S.F. Castro 2743 (EAC). Lavras da Mangabeira, Colégio Agrícola, 17.V.1985, fl., A. Fernandes et al. (EAC 13189). Uruoca, Morro Verde, 3.V.2006, fl., A.S.F. Castro 1769 (EAC).

Monnina insignis é facilmente reconhecida por ser uma erva com ramos e pecíolos recobertos por tricomas curtos e falciformes e ter carena trilobada e frutos nucóides, 2-alados. É endêmica do Brasil com distribuição limitada apenas à região Nordeste. No estado do Ceará foi registrada em áreas de savana e savana-estépica (Fig.1; B2, G6, H5, H6, I4, I5, I6). Constitui nova ocorrência para o estado. Coletada com flores de março a junho e frutos em junho e julho.

6.1. Polygala appendiculata Vell., Fl. flumin. 292. 1829.

Figs. 1; 3c

Erva 35-42 cm alt., pouco ramificada, glabra; ramos eretos, sem espinhos. Folhas alternas; lâmina 6-17 × 0,5-1,1 mm, lanceolada, ápice cuspidado, base atenuada; pecíolo 0,3-0,5 $\mathrm{mm}$; nectários extraflorais ausentes. Racemos espiciformes,
3,5-7,5 cm compr., na porção terminal dos ramos, densifloros; bractéola central ca. 1,1 mm compr., caduca. Flores alvo-amareladas; pedicelo 0,8-1 mm compr.; 1 sépala externa maior $0,8-1,1 \times 0,5-0,7$ $\mathrm{mm}$, elíptica, ápice acuminado; 2 sépalas externas menores $0,4-0,7 \times 0,2-0,3 \mathrm{~mm}$, lanceoladas, ápice agudo; 2 sépalas internas 1,6-2,1 ×0,6-0,8 mm, elípticas, ápice obtuso; pétalas laterais $1,2-1,5 \times$ 0,4-0,5 mm, elípticas, ápice obtuso; carena 1,3-1,8 $\mathrm{mm}$, ápice cristado; bainha estaminal 0,3-0,5 mm compr.; estames 8 , homodínamos, filetes ca. 0,2 mm compr.; ovário $0,5-0,7 \times 0,4-0,6 \mathrm{~mm}$, elíptico; estilete $0,4-0,5 \mathrm{~mm}$ compr., ereto; estigma globoso, cavidade pré-estigmática em forma de coifa, com tufo de tricomas no ápice. Cápsula 1,8-2,1 × 0,6-1 $\mathrm{mm}$, oblonga, sem glândulas cróceas ao longo do septo. Sementes 1,3-1,5 × 0,4-0,5 mm, obovadas, recobertas por tricomas hialinos eretos, sem coroa de tricomas na base; sem apêndices.

Material selecionado: Caucaia, Lagamar do Cauipe, 29.X.2008, fl. e fr., D.J.L. Sousa 60 (EAC). Eusébio, Ucaba, 20.VI.2004, fl. e fr., A.S.F. Castro 1482 (EAC).

Polygala appendiculata é um táxon bem delimitado e caracterizado por apresentar racemos espiciformes, cavidade pré-estigmática em forma de coifa com tufo de tricomas no ápice e sementes obovadas, sem apêndices. É nativa e endêmica do Brasil, ocorrendo em praticamente todos os estados do país, exceto Acre, Amapá, Tocantins e Rondônia. No Ceará foi encontrada apenas na região litorânea em floresta estacional semidecidual das terras baixas (Fig. 1; C6, C7). Coletada com flores e frutos em junho e outubro.

6.2. Polygala boliviensis A.W.Benn., J. Bot. 17: 171 . 1879.

Figs. 1; 3d-h

Erva 35-59 cm alt., pouco ramificada; ramos eretos, sem espinhos, com tricomas falciformes. Folhas verticiladas na porção inferior, alternas na porção superior; lâmina 5-12 × 0,8-1 mm, lanceolada, ápice mucronulado, base atenuada, glabra, com pontuações; pecíolo 0,3-0,5 mm compr.; nectários extraflorais ausentes. Racemos espiciformes, 3-10 cm compr., na porção terminal dos ramos, laxifloros; bractéola central $0,5 \mathrm{~mm}$ compr., caduca. Flores rosa pálido; pedicelo 0,6-1,2 mm compr., glabro; 1 sépala externa maior $1-1,5$ $\times 0,5-0,8 \mathrm{~mm}$, obovada, ápice agudo; 2 sépalas externas menores $1-1,2 \times 0,3-0,5 \mathrm{~mm}$, lanceoladas, ápice acuminado; 2 sépalas internas $3-4,7 \times 1-2$ $\mathrm{mm}$, elípticas, ápice obtuso; pétalas laterais 2,1-2,9 $\times 0,7-0,9 \mathrm{~mm}$, oblongas, ápice obtuso; carena 1,5-2,2 mm, ápice cristado; bainha estaminal 
0,4-0,6 mm compr.; estames 8, homodínamos, filetes ca. 0,1 mm compr.; ovário 0,4-0,6 × 0,2-0,3 mm, elíptico; estilete $0,5-0,6 \mathrm{~mm}$ compr., ereto; estigma globoso, cavidade pré-estigmática em forma de coifa, com tufo de tricomas no ápice. Cápsula 3-3,5 × 1-1,2 $\mathrm{mm}$, assimétrica, obovada, sem glândulas cróceas ao longo do septo. Sementes 3-3,5 × 0,4-0,6 mm, oblanceoladas, base truncada, recobertas por tricomas hialinos eretos, formando uma coroa de tricomas na base; apêndices 2 , com 0,3-0,5 mm compr., menores que a metade do comprimento da semente.

Material selecionado: Aiuaba, Estação Ecológica de Aiuaba, 30.IV.1981, fl. e fr., P. Martins (EAC 10248). Coreaú, Ubauna, 28.III.1994, fl. e fr., F.S Araújo \& M.A. Figueiredo (EAC 21369). Guaraciaba do Norte, Serra da Ibiapaba, 8.IV.1982, fl. e fr., P. Martins (EAC 11201). Jucás, rodovia CE 282, próximo à ponte sobre o Rio Jaguaribe, 31.II.2000, fl., E.B. Souza 502 (EAC). Limoeiro, 10.IV.2012, fl. e fr., Lúcio (EAC 31586). Parambú, Fazenda do Pau Preto, 22.V.1982, fl. e fr., L. Nunes (EAC 11424). Quixadá, Fazenda Iracema, 5.VI.1981, fl. e fr., E. Nunes (EAC 11531). Tauá, Fazenda Boa Vista, 28.V.1981, fl. e fr., E. Nunes \& Angelica (EAC 10100). Santa Quitéria, a 5 km da cidade, 7.III.2000, fl., A.S.F. Castro 806 (EAC). São Gonçalo, BR 222, 28.III.1994, fl. e fr., A.S.F. Castro (EAC 24040). Sobral, Fazenda Macapá, 23.V.1981, fl. e fr., $P$. Martins \& A. Fernandes (EAC 10280). Tianguá, Chapada da Ibiapaba, 24.IV.1980, fl., A. Fernandes \& E. Nunes (EAC 8529). Ubajara, Fazenda Japtarovo, 29.III.1994, fl. e fr., F.S. Araújo \& M.A. Figueiredo 650 (EAC).

Polygala boliviensis é a única espécie entre as registradas para o estado do Ceará que possui tricomas falciformes nos ramos. Podendo ainda ser reconhecida pelas folhas verticiladas na porção inferior e alternas na porção superior, racemos espiciformes, sementes com coroa de tricomas na base e apêndices menores que a metade do comprimento da semente. É morfologicamente semelhante à Polygala trichosperma, diferenciando-se desta pela presença de ramos com tricomas falciformes ( $v s$ ramos glabros) e racemos laxifloros ( $v s$ densifloros). Foi registrada em todos os estados da região Nordeste do Brasil. No território cearense é a espécie com a mais ampla distribuição e foi encontrada frequentemente associada a savana estépica (Fig. 1; C1, C2, C3, C5, C7, D1, D2, D3, D4, D5, E3, E4, E5, E6, F2, F3, F5, F6, F7, F8, G2, G3, H2, H3, H4, H5, I2, I3, I4). Coletada com flores nos meses de fevereiro a junho e com frutos de março a junho.

6.3. Polygala celosioides Mart. ex A.W.Benn., Fl. bras. 13(3): 64-65. 1874.

Figs. 1; 3i-k

Erva 3,5-23 cm alt., ramificada no ápice; ramos eretos, sem espinhos; ramos e pedicelos com tricomas glandulares. Folhas alterno-espiraladas; lâmina 3,7-11,3 ×0,2-0,8 mm, linear, ápice cuspidado, base cuneada, glabra; pecíolo ausente; nectários extraflorais ausentes. Racemos cônicos, 0,4-2 cm compr., na porção terminal dos ramos, densifloros; bractéola central 1,6 mm compr., persistentes depois do fruto. Flores róseas; pedicelo 0,2-0,5 mm compr.; 1 sépala externa maior 1,4-1,7 × 0,4-0,6 mm, lanceolada, ápice agudo; 2 sépalas externas menores $0,9-1,2 \times 0,4-0,6 \mathrm{~mm}$, lanceoladas, ápice acuminado; 2 sépalas internas 2-2,8 $\times 1,1-1,3 \mathrm{~mm}$, obovadas, ápice obtuso; pétalas laterais 1,9-2,3 $\times 0,8-1 \mathrm{~mm}$, lineares, ápice obtuso; carena 1,8-2,1 mm compr., ápice cristado; bainha estaminal $0,3-0,5 \mathrm{~mm}$ compr.; estames 8 , homodínamos, filetes ca. $0,1 \mathrm{~mm}$ compr.; ovário 0,2-0,4 × 0,3-0,4 mm, elíptico; estilete 0,3-0, $5 \mathrm{~mm}$ compr., uncinado; estigma globoso, cavidade pré-estigmática em forma de coifa com tufo de tricomas no ápice. Cápsula 1,5-1,8 × 0,9-1,1 mm, elíptica, sem glândulas cróceas ao longo do septo. Sementes 0,9-1,2 ×0,3-0,5 mm, estreito elípticas, curvas, glabras ou glabrescentes, sem coroa de tricomas na base; apêndices 2 , com $0,3-0,8 \mathrm{~mm}$ compr., do mesmo tamanho ou menores que a metade do comprimento da semente.

Material examinado: Granja, serra das Flores, 26.VIII.1977, fl., A. Fernandes (EAC 3458). Viçosa do Ceará, serra das Flores, 4.VIII.2005, fl., L.W. Lima Verde 3404-01 (EAC).

Polygala celosioides caracteriza-se por apresentar folhas alterno-espiraladas, racemos cônicos e sementes curvadas, glabras ou glabrescentes. É morfologicamente semelhante à Polygala sedoides, diferenciando-se desta por apresentar apêndices nas sementes (vs. apêndices ausentes). É endêmica do Brasil, ocorrendo em todas as regiões do país (BFG 2015). No Ceará foi registrada somente na savana (Fig. 1; B1, C1). Coletada com flores em agosto. Constitui nova ocorrência para o estado do Ceará.

6.4. Polygala glochidata Kunth, in Humb., Bonpl. \& Kunth, Nov. Gen et Sp. P1.,. 5: 400. 1823.

Figs. 1; 31,m

Erva 9-30 cm alt., pouco ramificada; ramos eretos, sem espinhos; ramos com tricomas glandulares. Folhas alternas na porção superior dos ramos e verticiladas na porção inferior; lâmina 4-15 × 0,8-1 mm, lanceolada, ápice acuminado, base cuneada, glabra; pecíolo ausente; nectários extraflorais ausentes. Racemos espiciformes, 2,5-6,7 cm compr., na porção terminal dos ramos, laxifloros; bractéola central ca. 0,3 mm compr., 
persistente nas flores. Flores arroxeadas; pedicelo $0,7-1,1 \mathrm{~mm}$ compr., glabro; 1 sépala externa maior $1-1,2 \times 0,6-0,8 \mathrm{~mm}$, elíptica, ápice acuminado; 2 sépalas externas menores $0,8-1,2 \times 0,3-0,4 \mathrm{~mm}$, lanceoladas, ápice acuminado; 2 sépalas internas 2,8-3 × 1-1,5 mm, elípticas, ápice obtuso; pétalas laterais $1,9-2,3 \times 0,5-0,7 \mathrm{~mm}$, lineares, ápice obtuso; carena 1,7-2,3 mm compr., ápice cristado; bainha estaminal $0,4-0,8 \mathrm{~mm}$ compr.; estames 8 , homodínamos, filetes ca. $0,1 \mathrm{~mm}$ compr.; ovário $0,9-1,2 \times 0,4-0,7 \mathrm{~mm}$, elíptico; estilete $0,5-0,8$ mm compr., uncinado; estigma globoso, cavidade pré-estigmática cimbiforme, com tufo de tricomas no ápice. Cápsula 1,6-2,1 × 0,9-1,1 mm, elíptica a oblonga, sem glândulas cróceas ao longo do septo. Sementes $0,8-1 \times 0,3-0,5 \mathrm{~mm}$, obovadas, recobertas por tricomas uncinados, hialinos, sem coroa de tricomas na base; sem apêndices.

Material selecionado: Caridade, Fazenda Feijão, 19.V.1991, fl. e fr., C. Luis (EAC 1874). Caucaia, Parque Botânico do Ceará, 29.IV.1998, fl. e fr., M.S. Lopes (EAC 26478). Crateús, RPPN Serra das Almas, 8.V.2002, fl., F.S. Araújo 1495 (EAC). General Sampaio, Fazenda do seu Elias, 31.V.2008, fl., M.F. Moro et al. 450 (EAC). Quixadá, Fazenda Não Me Deixes, 3.V.2000, fl. e fr., $A$. Fernandes (EAC 29831). Santa Quitéria, Serra do Pajé, 7.V.1997, fl. e fr., M.A. Figueiredo (EAC 25549). São Gonçalo do Amarante, Pecém, Zona Z4 UTM, 6.IV.2008, fl. e fr., M.F. Moro 386 (EAC).

Polygala glochidata é uma espécie bem delimitada e tem como principais características a presença de tricomas glandulares nos ramos, folhas sésseis e sementes com tricomas uncinados e sem apêndices. É nativa no Brasil, ocorrendo em todos os estados do país. No estado do Ceará tem ampla distribuição e foi encontrada preferencialmente na savana estépica (Fig. 1; C5, C6, C7, D3, D4, D5, D6, E3, E4, E5, E6, F2, F3, F5, F6). Registrada com flores e frutos em abril e maio.

6.5. Polygala gracilis Kunth, in Humb., Bonpl. $\&$ Kunth, Nov. Gen et Sp. Pl., 5, ed. 4: 401402.1823.

Figs. $1 ; 3 n$

Erva $33-50 \mathrm{~cm}$ alt.; ramificada; ramos eretos, sem espinhos; ramos glabros a laxamente pubérulos. Folhas alternas; lâmina 7-19 × 1-1,3 $\mathrm{mm}$, lanceolada, ápice cuspidado, base cuneada, glabra; pecíolo ca. 0,6 mm compr.; nectários extraflorais ausentes. Racemos espiciformes 6-11 cm compr., na porção terminal dos ramos, laxifloros; bractéola central ca. $0,8 \mathrm{~mm}$ compr., persistente no fruto. Flores alvo-amareladas; pedicelo $0,5-1 \mathrm{~mm}$ compr., glabros; 1 sépala externa maior $0,8-1 \times 0,5-0,8 \mathrm{~mm}$, obovada, ápice acuminado; 2 sépalas externas menores $0,6-0,8$ $\times 0,3-0,4 \mathrm{~mm}$, lanceoladas, ápice acuminado; 2 sépalas internas $2,8-3 \times 1-1,5 \mathrm{~mm}$, obovadas, ápice obtuso; pétalas laterais, $2-2,3 \times 0,5-0,6 \mathrm{~mm}$, obovada, ápice arredondado; carena 2,3-3 mm compr., ápice cristado; bainha estaminal 0,5-0,6 $\mathrm{mm}$ compr., estames 8 , homodínamos, filetes ca. $0,2 \mathrm{~mm}$ compr.; ovário $0,6-0,9 \times 0,4-0,6 \mathrm{~mm}$; elíptico; estilete $0,1-0,4 \mathrm{~mm}$ compr., uncinado; estigma globoso; cavidade pré-estigmática em forma de coifa, com tufo de tricomas no ápice. Cápsula 2,4-3 × 1,5-1,8 mm, oblonga a cilíndricas, sem glândulas cróceas ao longo do septo. Sementes $2,2-2,6 \times 0,4-0,5 \mathrm{~mm}$, obovadas, recobertas por tricomas hialinos eretos, sem coroa de tricomas na base; apêndices 2 , com $0,8-1 \mathrm{~mm}$ compr., menores que a metade do comprimento da semente.

Material selecionado: Crato, Flona do Araripe, 15.VI.2000, fl. e fr., L.W. Lima Verde 2057 (EAC). São Benedito, Faveira, 27.VI.1981, fl. e fr., A. Fernandes (EAC 10456).

Polygala gracilis caracteriza-se por ser uma erva muito ramificada e possuir racemos espiciformes laxifloros e sementes obovadas com dois apêndices, revestidas por tricomas eretos. Entre espécies ocorrentes no Ceará, apresenta afinidades com $P$. paniculata, diferenciado-se principalmente por apresentar sementes com apêndices menores que a metade do comprimento da semente ( $v s$. do mesmo tamanho ou maiores que a metade do comprimento da semente). É nativa do Brasil, ocorrendo em todos os estados do país. No Ceará foi encontrada em áreas de savana estépica e floresta estacional decidual sempre verde (Fig.1; D1, D2, J4, J5). Coletada com flores e frutos em maio.

6.6. Polygala longicaulis Kunth, in Humb., Bonpl. $\&$ Kunth, Nov. Gen. et Sp. Pl., 5: 396. 1823. nom. cons.

Figs. 1 ; 3o-q

Erva 14-21 cm alt., pouco ramificada; ramos eretos, sem espinhos, com tricomas lepidotos. Folhas alternas; lâmina 10-17 × 1-0,6 mm, linear, ápice mucronado, base atenuada, glabra, com pontuações, séssil a curto peciolada; pecíolo $0,2-1 \times 0,1 \mathrm{~mm}$ compr.; nectários extraflorais ausentes. Racemos subcapitados $0,5-2 \mathrm{~cm}$ compr., densifloros; bractéola central $0,8 \mathrm{~mm}$, caduca. Flores róseas a arroxeadas; pedicelo 0,6-1,2 mm compr., glabros; 1 sépala externa maior 1,8-2,5 × $0,8-1 \mathrm{~mm}$, estreitamente elíptica, ápice acuminado; 2 sépalas externas menores $1,5-2 \times 0,3-0,7 \mathrm{~mm}$, lanceoladas, ápice acuminado; 2 sépalas internas 
4-5,2 × 2,1-3 mm, obovadas, ápice mucronado; pétalas laterais 4-4,5 × 1-1,2 mm, linear, ápice obtuso; carena 4,2-5 mm compr., ápice cristado; bainha estaminal $0,6-0,8 \mathrm{~mm}$ compr., estames 8 , homodínamos, filetes ca. 0,2 mm compr.; ovário 1,2-1,8 × 0,5-0,8 mm; estreitamente elíptico; estilete 1,2-1,5mm compr., alongado; estigma globoso; cavidade pré-estigmática em forma de coifa, com tufo de tricomas no ápice. Cápsula 3,8-4,2 × $2 \mathrm{~mm}$, elíptica a oblonga, com glândulas cróceas ao longo do septo. Sementes $1-2 \times 0,4-0,6$ $\mathrm{mm}$, triangulares com base truncada, recobertas por tricomas hialinos eretos, formando uma coroa de tricomas na base; sem apêndices.

Material examinado: Cratéus, RPPN Serra das Almas, 23.III.2002, fl. e fr., F.S. Araújo et al. 1385 (EAC). São Gonçalo do Amarante, Pecém, 6.IV.2008, fl. e fr., M.F. Moro 386 (EAC). Sobral, Sítios Novos, 29.IV.2006, fl. e fr., M. Oliveira 2302 (UFP).

Polygala longicaulis assemelha-se a $P$. trichosperma por compartilharem racemos densifloros e sementes triangulares; porém, diferencia-se por apresentar sementes com coroa de tricomas hialinos na base e ausência de apêndices. É endêmica do Brasil, ocorrendo em todos os estados do país, exceto no Acre, Rondônia, Alagoas e Rio de Janeiro. No estado do Ceará foi considerada uma espécie rara, por estar representada por apenas duas coletas realizadas em vegetação de savana estépica e floresta estacional semidecidual das terras baixas (Fig.1; C6, F2). Coletada com flores e frutos em março e abril.

6.7. Polygala paniculata L., Syst. Nat. ed. 10: 1154. 1759.

Figs. 1; 4a,b

Erva $13-37 \mathrm{~cm}$ alt., ramificada no ápice; ramos eretos, sem espinhos, com tricomas lepidotos. Folhas alternas na porção superior e verticiladas na porção inferior; lâmina 4-27 × 1-4 $\mathrm{mm}$, linear, ápice agudo, base cuneada, glabra, com pontuações, séssil a curto peciolada; pecíolo 0,1-0,6 × 0,2 mm compr.; nectários extraflorais ausentes. Racemos espiciformes $1-8 \mathrm{~cm}$ compr., laxifloros; bractéola central $0,9 \mathrm{~mm}$, caducas. Flores alvas; pedicelo $0,2-1 \mathrm{~mm}$ compr., glabros; 1 sépala externa maior $1 \times 0,3-0,6 \mathrm{~mm}$, ovada, ápice agudo; 2 sépalas externas menores $0,6-1 \times 0,3-0,6$ $\mathrm{mm}$, estreitamente ovadas, ápice acuminado; 2 sépalas internas $1-2,1 \times 0,6-1,1 \mathrm{~mm}$, obovadas, ápice agudo; pétalas laterais 1,8-2 ×0,7-0,9 mm, linear, ápice obtuso; carena 2-2,3 mm compr., ápice cristado; bainha estaminal $0,8-1,2 \mathrm{~mm}$, estames 8 , homodínamos, filetes ca. 0,2 mm compr.; ovário
0,4-0,6 × 0,3-0,4 mm; oblongo; estilete 0,4-0,5 mm compr., uncinado; estigma globoso; cavidade pré-estigmática em forma de coifa, com tufo de tricomas no ápice. Cápsula ca. $2 \times 1 \mathrm{~mm}$, oblonga, sem glândulas cróceas ao longo do septo. Sementes $1,2-2 \times 0,5 \mathrm{~mm}$, estreitamente elípticas, recobertas por tricomas hialinos eretos, sem coroa de tricomas; dois apêndices, com 0,6-1,2 mm compr.,

Material selecionado: Baturité, Sítio Olho D’água dos Tanguarás, 10.VIII.1995, fl. e fr., L.W. Lima-Verde (EAC 22402). Guaraciaba do Norte, Serra da Ibiapina, 15.VI.1979, fl. e fr., A. Fernandes, et al. (EAC 6565). Guaramiranga, Pico Alto, 20.V.2004, fl. e fr., E. Silveira (EAC 33878).

Polygala paniculata caracteriza-se pelos ramos recobertos por tricomas lepidotos, folhas lineares, glabras, com pontuações, alternas na porção superior e verticiladas na porção inferior, e racemos espiciformes. Como citado anteriormente, é morfologicamente semelhante à $P$. gracilis, diferenciando-se por apresentar sementes com apêndices do mesmo tamanho ou maiores que a metade do comprimento da semente ( $v s$. menores que a metade do comprimento da semente). Polygala paniculata tem ampla distribuição no Brasil, ocorrendo em todas as regiões. No estado do Ceará foi registrada na floresta estacional semidecidual, savana e floresta ombrófila (Fig. 1; C2, D6). Coletada com flores e frutos durante todo o ano.

6.8. Polygala sedoides A.W.Benn., Fl. bras. 13(3): 27-28, t. 10, f. 3. 1874.

Figs. 1; 4c,d

Erva ca. $0,38 \mathrm{~cm}$ alt., pouco ramificada no ápice; ramos eretos, sem espinhos; ramos e folhas glabros a esparsamente pubérulo. Folhas verticiladas; lâmina $3,2-4,5 \times 0,2-0,3 \mathrm{~mm}$, linear, ápice acuminado, base cuneada; pecíolo ausente; nectários extraflorais ausentes. Racemos cônicos, 0,3-0,5 cm compr., na porção terminal dos ramos, densifloros; bractéola central 0,9 mm, persistente no fruto. Flores alvas; pedicelo 0,1-0,2 mm compr., glabros; 1 sépala externa maior 0,8 $\times 0,2 \mathrm{~mm}$, obovada, ápice acuminado; 2 sépalas externas menores $0,4 \times 0,1 \mathrm{~mm}$, lanceoladas, ápice acuminado; 2 sépalas internas $1,8 \times 1,1 \mathrm{~mm}$, elípticas, ápice obtuso; estames 8 , homodínamos, filetes 0,3-0,4 mm compr. Cápsula ca. 0,8 × $1 \mathrm{~mm}$, elíptica, sem glândulas cróceas ao longo do septo. Sementes ca. $0,7 \times 0,2 \mathrm{~mm}$, ovadas, recobertas por tricomas hialinos eretos; sem coroa de tricomas na base; sem apêndices.

Material examinado: fr., Schwacke 1276 (RB). 

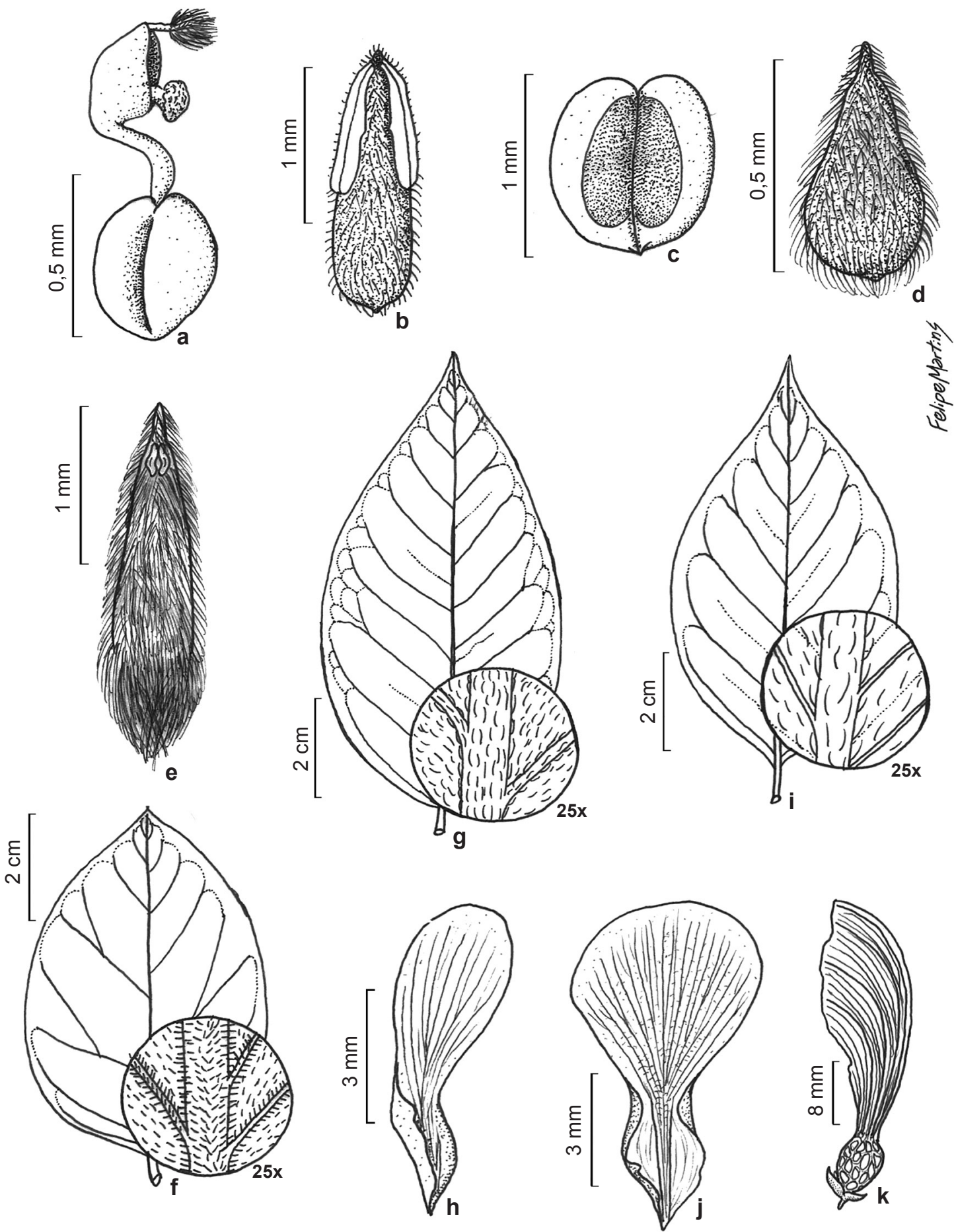

Figura 4 - a-b. Polygala paniculata - a. gineceu; b. semente. c-d. P. sedoides - c. fruto; d. semente. e. P. trichosperma - e. semente. f. Securidaca coriacea - f. face abaxial da folha. g-h. S. diversifolia - g. face abaxial da folha; h. pétala lateral externa. i-k. S. lanceolata - i. face adaxial da folha; j. pétala lateral externa; k. fruto. (a-b. E. Silveira - EAC 33878; c-d. Schwacke 1276; e. E. Nunes - EAC 11530; f. F.S. Araújo 485; g-h. M.A.P. Silva - EAC 25971; i-k. .S. Sampaio 115)

Figure 4 - a-b. Polygala paniculata - a. gynoecium; b. seed. c-d. P. sedoides - c. fruit; d. seed. e. P. trichosperma - e. seed; f. Securidaca coriacea -f. adaxial side of leaf. g-h. S. diversifolia - g. adaxial side of leaf; h. outer lateral petal. i-k. S. lanceolata -i. adaxial side of leaf; j. outer lateral petal; $\mathrm{k}$. fruit. (a-b. E. Silveira-EAC 33878; c-d. Schwacke 1276; e. E. Nunes-EAC 11530; f. F.S. Araújo 485; g-h. M.A.P. Silva-EAC 25971; i-k. S. Sampaio 115) 
Polygala sedoides caracteriza-se por ter folhas lineares e verticiladas, racemos cônicos e densifloros e sementes ovadas, recobertas por tricomas eretos. É morfologicamente semelhante à Polygala celosioides, diferenciado-se por apresentar sementes sem apêndices ( $v s$ semente com apêndice). É endêmica do Brasil, ocorrendo nas regiões Norte, Nordeste e Centro-Oeste. Por ser uma coleção muito antiga, não foi possível observar todas as estruturas florais. Nesta coleção também não foi indicado o local e nem a data da coleta.

6.9. Polygala trichosperma Jacq, Observ. Bot., v. 3, p.16, 1763.

Figs. 1; 4e

Erva $10,8-36 \mathrm{~cm}$ alt.; pouco ramificada, glabra; ramos eretos, sem espinhos. Folhas alternas; lâmina 6-11 × 0,5-1,1 mm, lanceolada, ápice agudo, base atenuada; pecíolo $0,4-0,5$ $\mathrm{mm}$ compr.; nectários extraflorais ausentes. Racemos subcapitados 0,6-1,2 cm compr., na porção terminal dos ramos, densifloros; bractéola central ca. $1 \mathrm{~mm}$, caduca. Flores alvo-amareladas; pedicelo $0,6-0,8 \mathrm{~mm}$ compr.; 1 sépala externa maior 1,5-1,7 ×0,6-1 mm, obovada, ápice agudo; 2 sépalas externas menores $1-1,2 \times 0,3-0,4 \mathrm{~mm}$, lanceoladas, ápice agudo, 2 sépalas internas $4-5,1 \times$ 1,6-2 mm, elípticas, ápice obtuso; 2 pétalas laterais 2-2,3 $\times 0,8-1,1 \mathrm{~mm}$, obovadas, ápice arredondado; carena 2,1-3,1 mm compr., ápice cristado; bainha estaminal ca. $0,5 \mathrm{~mm}$ compr., estames 8 , homodínamos, filetes ca. $0,4 \mathrm{~mm}$ compr.; ovário $0,5-1,1 \times 0,5-0,6 \mathrm{~mm}$, elíptico; estilete $0,3-0,8$ $\mathrm{mm}$ compr., curto-ereto; estigma globoso; cavidade pré-estigmática em forma de coifa, com tufo de tricomas no ápice. Cápsula 2,8-4 × 1-1,9 mm, trulada, com glândulas cróceas ao longo do septo. Sementes 1,4-2 × 0,7-0,8 mm, cônicas, recobertas por tricomas hialinos eretos, formando uma coroa de tricomas na base; apêndices $0,1-0,3 \mathrm{~mm}$ compr., menores que a metade do comprimento da semente. Material selecionado: Aquiraz, serrote da Preaoca, 4.VII.1999, fl. e fr., A.S.F. Castro 721 (EAC). Quixadá, Fazenda Iracema, 5.VI.1982, fl. e fr., E Nunes (EAC 11530). Coreaú, Ubauna, 28.III.1994, fl. e fr., A.M. Figueiredo (EAC 29421). Jaguaribe, Maciço do Pereiro, 12.IV.2011, fl. e fr., A.M. Miranda 6334 (HST).

Polygala trichosperma tem como características marcantes os ramos glabros, folhas lanceoladas e alternas, racemos subcapitados e densifloros, cápsula trulada, com glândulas cróceas ao longo do septo, sementes com coroa de tricomas na base. Diferencia-se de P. longicaulis por apresentar apêndices nas sementes ( $v s$. ausentes) e de $P$. boliviensis por ter ramos glabros (vs. ramos com tricomas falciformes). É nativa do Brasil, ocorrendo em todos os estados do norte e nordeste, com exceção do Acre. No Ceará foi encontrada na savana estépica (Fig. 1; C2, C7, D7, E5, E6, G6, H6). Coletada com flores e frutos entre março e julho.

7.1. Securidaca coriacea Bonpl., Mag. Neuesten Entdeck. Gesammten Naturk. Ges. Naturf. Freunde Berlin 2: 47. 1808.

Figs. 1; 4f

Arbusto 1,0-2 m alt., muito ramificado; ramos escandentes, sem espinhos; ramos jovens, pecíolos e pedicelos densamente pubérulos. Folhas alternas; lâmina $35-75 \times 32-45 \mathrm{~mm}$, ovada, raro oblonga, ápice agudo, atenuado ou obtuso, base arredondada, raro aguda, margem revoluta, face adaxial glabra a glabrescente, opaca, face abaxial revestida por tricomas patentes; pecíolo 3-5 mm compr.; nectários extraflorais circulares com sulco central, 0,1-0,2 mm compr., na base dos pecíolos e flores. Racemos 4-10,3 cm compr., nas porções terminais dos ramos, raque densamente pubérula; bractéola central 1,7-2 compr., lanceolada a aculiforme, pubérula. Flores roxas; pedicelo 4-6 mm compr.; 1 sépala externa maior 3-4,1 × 2,8-3,5 mm, (largo-)ovada a oval, côncava, ápice arredondado a obtuso, levemente emarginado, dorso pubérulo na base, ciliada; 2 sépalas externas menores $3-3,3 \times 1,5-2 \mathrm{~mm}$, ovadas, ápice obtuso, dorso velutino, ciliadas; 2 sépalas internas 9-10 × 6,5-7,1 $\mathrm{mm}$, petalóides, laterais, unguiculadas na base, obovadas a espatuladas, ápice arredondado, ciliadas ou não; 2 pétalas externas $7-8 \times 2-2,8 \mathrm{~mm}$, estreitoobovadas a suboblongas, ápice arredondado, base aguda, presas basalmente à bainha estaminal, dorso glabro, pubérula internamente na região mediana; 2 pétalas rudimentares ca. $1-1,2 \times 0,8-1$ $\mathrm{mm}$, ovalada, ápice obtuso, glabras; carena 7,5-10 $\times 8,5-9,2 \mathrm{~mm}$, navicular, cuculada, com crista flabelo-plicada, ciliada, conata basalmente à bainha estaminal; bainha estaminal côncava, densamente vilosa no ventre, dorso glabro, ciliada na porção basal; estames 8 , homodínamos, filetes 2,2-3,1 mm compr.; ovário $0,8-1,2 \times 1$, elíptico, achatado, densamente piloso na giba; estilete $8-9,5 \mathrm{~mm}$ compr., curvado, sinuoso, glabro. Sâmara 40-53× 12-16 mm, 1-alada, pubérula, núcleo seminífero reticulado-foveolado-cristado. Semente 5,3-6 $\times$ $4,2-5 \mathrm{~mm}$, oval, glabra, recoberta por tegumento tenuíssimo, com estrias partindo da micrópila que circundam a semente. 
Material examinado: Alcântaras, St. Antônio dos Camilos, Serra da Meruoca, 4.XII.2002, fr., $A$. Fernandes (EAC 32299). Capistrano, Serra do Vicente, 18.X.1979, fl., Angelica (EAC 7143). Crato, Flona, 5.X.2000, fl., F.S. Cavalcanti et al. 814 (EAC). Guaramiranga, Sítio Uruguaiana, 13.XI.1993, fl., M.R. Oliveira (EAC 21357). Novo Oriente, Planalto da Ibiapaba, 3.VII.1991, fl., F.S. Araújo 485 (EAC). Pacoti, Santa Madalena, 9.X.1980, fl.,fr., P. Martins et al. (EAC 8954).

Material adicional: Codó, Maranhão, Torre da Embratel, 15.VIII.2004, fl. e fr., L.W. Lima-Verde 2633 (EAC). União, Piauí, PI-112, 28.VII.1979, fl., $A$. Fernandes et al. (EAC 6830).

Securidaca coriacea é uma espécie bem delimitada e distingue-se das demais espécies do gênero ocorrentes no estado do Ceará por ser um arbusto escandente com folhas ovadas e face abaxial revestida por indumento ereto ou adpresso-ereto, tornando-se aveludado ao toque. Em território brasileiro tem ocorrência confirmada apenas nas regiões Norte e Nordeste. No Ceará foi registrada em floresta ombrófila densa, floresta estacional decidual sempre verde e savanaestépica (Fig. 1; C2, D5, D6, E6, F2, G2, J4, J5). Coletada com flores em julho, agosto e outubro e frutos de outubro a dezembro.

7.2. Securidaca diversifolia (L.) S.F.Blake, Contr. Gray Herb. 47: 15. $1916 . \quad$ Figs. 1; 4g,h

Arbusto até $3 \mathrm{~m}$ alt., muito ramificado; ramos eretos ou escandentes, sem espinhos; ramos jovens, pecíolos e pedicelos densamente pubérulos. Folhas alternas; lâmina 38-90 × 2-46 mm, ovada, ápice agudo, base arredondada, raro aguda, margem revoluta, face adaxial glabra ou com esparso indumento principalmente nas nervuras, face abaxial revestida por tricomas adpressos; pecíolo 3-7 mm compr.; nectários extraflorais circulares com sulco central, 0,1-0,2 mm compr., na base dos pecíolos e flores. Racemos 4,2-11 cm compr., nas porções terminais dos ramos, raque densamente pubérula; bractéola central 2-4 mm compr., lanceolada a aculiforme, pubérula. Flores roxas a rosadas; pedicelo 4-5 $\mathrm{mm}$ compr.; 1 sépala externa maior 3,7-4,1 × 2,3-3,1 mm, ovada, côncava, ápice obtuso, dorso pubérulo, ciliada; 2 sépalas externas menores 3-3,3 × 1,5-2,8 mm, ovadas, ápice arredondado a obtuso, ligeiramente irregulares na base, dorso velutino, ciliadas; 2 sépalas internas 7-9 × 6,5-7,8 $\mathrm{mm}$, petaloides, laterais, unguiculadas na base, orbiculares a suborbiculares, ápice arredondado, ligeiramente ciliadas; 2 pétalas laterais externas $7-9 \times 1,8-2,4$ mm, obovadas a subobovadas, ápice arredondado, presas basalmente à bainha estaminal, sem cílios, pubérula internamente na região mediana; 2 pétalas laterais internas rudimentares $1-1,3 \times$ 0,6-0,7 mm, ovais, ápice obtuso, glabras; carena $7-8,8 \times 7,3-8 \mathrm{~mm}$, navicular, cuculada, ciliada, com crista flabelo-plicada, conata basalmente à bainha estaminal; bainha estaminal côncava, densamente vilosa no ventre, ciliada e dorso glabro; estames 8, homodínamos, filetes 2,5-3 mm compr.; ovário 0,8-1 mm diâm., elíptico, achatado, viloso apenas na parte superior de um dos lados; estilete 8,5-9,5 mm compr., curvado, sinuoso, glabro. Sâmara 30-48 × 12-20 mm, 1-alada, pubérula, núcleo seminífero reticuladofoveolado-cristado. Semente 5-5,2 × 3,5-4,1 mm, oval, glabra, recoberta por tegumento tenuíssimo, com estrias partindo da micrópila que circundam a semente.

Material selecionado: Aquiraz, próximo ao Serrote, 7.XII.1998, fr., A.S.F. Castro (EAC 27239). Crato, Barreiro Grande, 6.XI.1997, fl. e fr., M.A.P. Silva (EAC 25971). Granja, Fazenda Recanto, 13.X.1989, fl., F. Cavalcante et al. (EAC 16219).

Material adicional: BAHIA: Jacobina, Bahia, Morro do Ouro, 11.III.1987, fl., A. Fernandes et al. (EAC 15042).

Securidaca diversifolia diferenciase de $S$. lanceolata, espécie mais próxima morfologicamente, por apresentar folhas ovadas ( $v s$. lanceoladas a elípticas) e pétalas laterais externas obovadas a subobovadas ( $v s$. subespatuladas). Espécie nativa do Brasil com distribuição em todas as regiões do país. No estado do Ceará foi registrada na savana, floresta estacional decidual sempre verde e floresta estacional semidecidual das terras baixas (Fig. 1; B1, B2, B3, C1, C7, D7, J4, J5). Coletada com flores de agosto a novembro e frutos de outubro a janeiro. Popularmente chamada "caninana".

7.3. Securidaca lanceolata A.St.-Hil. \& Moq., Fl. bras. Merid. (quarto ed.) 2(12): 69-70. 1829.

Fig. 1; 4i-k

Arbusto até $2 \mathrm{~m}$ alt., muito ramificado; ramos escandentes ou eretos, sem espinhos; ramos jovens, pecíolos e pedicelos densamente pubérulos. Folhas alternas; lâmina 42-89 × 16-46 $\mathrm{mm}$, lanceolada a elíptica, ápice agudo, base aguda, raro arredondado, margem revoluta, face adaxial e face abaxial revestidas por tricomas adpressos; pecíolo 3-7 mm compr.; nectários extraflorais circulares com sulco central, $0,1-0,2$ $\mathrm{mm}$ compr., na base dos pecíolos e flores. 
Racemos 5-12 cm compr., nas porções terminais dos ramos, raque densamente pubérula; bractéola central 1,8-3 mm compr., lanceolada a aculiforme, pubérula. Flores roxas; pedicelo 5,8-7 $\mathrm{mm}$ compr.; 1 sépala externa maior 3,8-5 × 3-3,5 mm, ovada, côncava, ápice obtuso, dorso pubérulo; 2 sépalas externas menores 3-3,3 × 1,5-2 mm, ovadas, ápice obtuso, dorso velutino; 2 sépalas internas $9-11 \times$ $6,5-8,5 \mathrm{~mm}$, petalóides, laterais, unguiculadas na base, ovadas a orbiculares, ápice arredondado, ligeiramente ciliadas; 2 pétalas laterais externas 8,3-9 × 4,1-5 $\mathrm{mm}$, subespatuladas, ápice ligeiramente flabelado, presas basalmente à bainha estaminal, ciliadas, pubérula internamente na região mediana; 2 pétalas laterais internas rudimentares ca. $1,2-1,4 \times 0,5-0,8 \mathrm{~mm}$, ovais, ápice obtuso, glabra; carena 7-8,5 × 8-8,8 $\mathrm{mm}$, navicular, cuculada, ciliada, com crista flabeloplicada, conata basalmente à bainha estaminal; bainha estaminal côncava, densamente vilosa no ventre, ciliada e dorso glabro; estames 8 , homodínamos, filetes 2,8-3 mm compr.; ovário ca. 0,8 mm diâm., elíptico, achatado, viloso apenas na parte superior de um dos lados; estilete 9-10 mm compr., curvado, sinuoso, glabro. Sâmara 40-61 × 13-18 mm, 1-alada, pubérula, núcleo seminífero reticulado-foveolado-cristado. Semente 5-5,3 $\times$ $3,5-4,2 \mathrm{~mm}$, oval, glabra, recoberta por tegumento tenuíssimo, com estrias partindo da micrópila que circundam a semente.

Material selecionado: Aratuba, Sítio Chave, 16.X.1979, fr., E. Nunes (EAC 7102). Caucaia, Serra do Juá, 21.XI.2014, fl., V.S. Sampaio 115 (EAC). Crato, Flona do Araripe, 12.VIII.1999, fl., L.W. LimaVerde 1599 (EAC). Guaramiranga, 1.I.1997, fl., A.S.F. Castro (EAC 24567). Maranguape, Serra da Aratanha, 24.X.1953, fl., P. Bezerra (EAC 953). Meruoca, 3.I.1955, fr., A. Fernandes (EAC 1067). Pacoti, Pico Alto/Serra de Baturité, 11.XI.1998, fl. e fr., E.B. Souza et al. 301 (EAC).

Securidaca lanceolata tem afinidades morfológicas com $S$. diversifolia, no entanto as distinguimos pelas seguintes características em S. lanceolata: folhas lanceoladas a elípticas (vs. ovadas) e pétalas laterais externas subespatuladas (vs. obovadas a subobovadas). É uma espécie endêmica do Brasil que está restrita às regiões Nordeste, Sudeste e Sul. No estado do Ceará a ocorrência da espécie está associada principalmente a áreas de floresta ombrófila densa no Maciço de Baturité e serra de Maranguape (Fig. 1; C3, C6, D5, D6, J4, J5). Coletada com flores de agosto a dezembro e frutos de setembro a janeiro. Popularmente conhecida como "caninana".

\section{Agradecimentos}

Ao CNPq, as bolsas de Iniciação Científica concedidas aos dois primeiros autores; aos funcionários e curadores dos herbários BHCB, EAC, HST, HVASF e RB, o suporte e envio de material para análise; aos projetos INCT - Herbário Virtual da Flora e Fungos do Brasil (Processo 573.883/2008-4); Rede Integrada em Taxonomia de Plantas e Fungos - SISBIOTA BRASIL (Processo No 563.342/2010-2); a Felipe Martins Guedes, a elaboração das pranchas ilustrativas; Maria Iracema Bezerra Loiola agradece ao CNPq, a Bolsa de Produtividade Nível 2 concedida.

\section{Referências}

Aguiar ACA \& Aranha J (2008) A família Polygalaceae na planície litorânea de Picinguaba, Ubatuba, São Paulo, Brasil. Revista Brasileira de Biociências 6: 321-328.

Araújo FS, Costa RC, Lima JR, Vasconcelos SF, Girão LC, Sobrinho MS, Bruno MMA, Souza SSG, Nunes EP, Figueiredo MA, Lima-Verde LW \& Loiola MIB (2011) Floristics and life-forms along a topographic gradiente, central-wester Ceará, Brazil. Rodriguesia 62: 341-366

Bennett AW (1874) Polygalaceae. In: Martius CFP von, Eichler AW \& Urban IG (eds.) Flora brasiliensis. Munchen, Wien, Leipzig. Vol. 13, pp. 1-82.

BFG - The Brazil Flora Group (2015) Growing knowledge: an overview of seed plant diversity in Brazil. Rodriguésia 66: 1085-1113.

Capistrano SHB \& Loiola MIB (2015) Flora do Ceará, Brasil: Krameriaceae. Rodriguésia 66: 905-912.

Coelho VPM, Agra MF \& Baracho GS (2008) Flora da Paraíba, Brasil: Polygala L. (Polygalaceae). Acta Botanica Brasilica 22: 225-239.

Ferreira DMC \& Alves M (2015) Polygalaceae. In: Prata APN; Farias MCV \& Landim MF (orgs.) Flora de Sergipe. Vol 2. Criação Editora, Aracaju. Pp. 224-242.

IBGE - Instituto Brasileiro de Geografia e Estatística (2012) Manual técnico da vegetação brasileira. $2^{\mathrm{a}}$ ed. Disponível em <http://biblioteca.ibge.gov.br/ visualizacao/livros/ liv63011.pdf $>$. Acesso em 10 setembro 2015.

IPECE - Instituto de Pesquisa e Estratégia Econômica do Ceará (2013) Ceará em números. Disponível em <http://www2.ipece.ce.gov.br/publicacoes/ ceara_em_numeros/2013/ completa/Ceara_em Numeros 2013.pdf $>$. Acesso em 23 maio 2016.

IPNI - The International Plant Names Index (2017) The International Plant Names Index. The Royal Botanic Gardens, Kew. Disponível em <http://www.ipni. org $>$. Acesso em 20 abril 2017.

Leite WP, Aguiar-Dias AC \& Fieroo-Freire AM (2015) Pollen diversity in Brazilian species of Monnina (Polygalaceae). Phytotaxa 220: 117-126. 
Lemos RPL, Mota MCS, Chagas EEO \& Silva FC Polygalaceae. In: Lemos RPL, Mota MCS, Chagas EEO \& Silva FC (eds.) Checklist flora de Alagoas: angiospermas. Vol. 1. Instituto do Meio Ambiente de Alagoas, Maceió. 77p.

Lima LC, Morais JO \& Souza MJN (2000) Compartimentação territorial e gestão regional do Ceará. FUNECE, Fortaleza. 268p.

Loiola MIB (2013) A new species of Erythroxylum (Erythroxylaceae) from the Brazilian semiarid region. Phytotaxa 150: 61-64.

Loiola MIB, Araújo FS, Lima-Verde LW, Souza SSG, Matias LQ, Menezes MOT, Silva MAP, Souza MMA, Mendonça ACAM, Macedo MS, Oliveira SF, Sousa RS, Balcázard AL, Crepaldi CG, Campos LZO, Nascimento LGS, Cavalcanti MCBT, Oliveira RD, Silva TC \& Albuquerque UP (2015) Flora da Chapada do Araripe. In: Albuquerque MVM (org.) Sociobiodiversidade na Chapada do Araripe. Vol. 1. NUPEEA, Recife. Pp. 103-148.

Marques MCM (1996) Securidaca L. (Polygalaceae) do Brasil. Arquivos do Jardim Botânico do Rio de Janeiro 34: 7-144.

Marques MCM \& Peixoto ALP(2007) Estudo Taxonômico de Polygala subgênero Ligustrina (Chodat) Paiva (Polygalaceae). Rodriguésia 58: 95-146.

Menezes MOT, Taylor NP \& Loiola MIB (2013) Flora of Ceará, Brazil: Cactaceae. Rodriguésia 64: 757-774.

Nimer E (1972) Climatologia da Região Nordeste do Brasil: subsídios à geografia regional do Brasil. Revista Brasileira de Geografia 34: 5-51.

Oliveira MDF \& Silveira ER (2000) Pentaoxygenated, xatones and fatty acids from Bredmeyera brevifolia. Phytochemistry 55: 847-851.

Paiva JAR (1988) Prodromus atque gerontogæi generis heterosamara kuntze, a genere Polygala 1 . segregati et a nobis denuo recepti, synopsis monographica. Fontqueria 50: 1-346.

Pastore JFB (2006) Polygalaceae Hoffmannsegg \& Link no Distrito Federal, Brasil. Dissertação de Mestrado. Universidade de Brasília, Brasília. 216p.

Pastore JB (2016) Acanthocladus dichromus, a new combination for a South American Polygalaceae. Phytotaxa 286: 54-56.

Pastore JFB \& Abbott JR (2012) Taxonomic notes and new combinations for Asemeia (Polygalaceae). Kew Bulletin 67: 1-13.

Pizzolatti MG, Cunha AJR, Pereira WS \& Monache FD (2004) A new styryl-2-pyrone derivative from Polygala sabulosa (Polygalaceae). Biochemical Systematics and Ecology 32: 603-606.

Radford AE, Dickson WC, Massey JR \& Bell CR (1974) Vascular plant systematics. Harper \& Row, New York. 498p.

Ribeiro RTM, Soares Neto RL \& Loiola MIB (2017) Phyllanthus carmenluciae, a supreme species of Phyllanthus (Phyllantaceae) from Brazil. Phytotaxa: 305: 35-40.

Sampaio VS, Moura RL \& Loiola MIB (2016) Solanum fernandesii (Solanaceae): A new species of 'spiny solanum' of the Gardneri clade from northeastern Brazil. Phytotaxa 270: 33-40.

Silveira ER, Falcão MJC \& Menezes A (1995) Pentaoxygenated xanthomes from Bredemeyera floribunda. Phytochemistry 39: 1433-1436.

Souza EB, Miguel LM, Cabral EL, Nepomuceno FAA \& Loiola MIB (2016) Borreria apodiensis (Rubiaceae: Spermacoceae), a new species from Ceará and Rio Grande do Norte, Brazil. Acta Botanica Brasilica 30: 283-289.

Stearn WT (1992) Botanical latin. $4^{\text {th }}$ ed. David \& Charles Book, Redwood Press, Edinburgh. 546p.

Tabosa FRS, Almeida EM, Melo E \& Loiola MIB (2016) Flora do Ceará, Brasil: Polygonaceae. Rodriguésia 67: 981-996.

Thiers B [continuously updated] Index Herbariorum: a global directory of public herbaria and associated staff. New York Botanical Garden's Virtual Herbarium. Disponível em $<$ http://sweetgum.nybg. org/science/ih/>. Acesso em 14 fevereiro 2016.

Victório CP, Carriço JB \& Lage CL (2011) Polygala paniculata: a source of methyl salicylate produced through plant tissue culture. Revista Ceres 58: 269-272. 